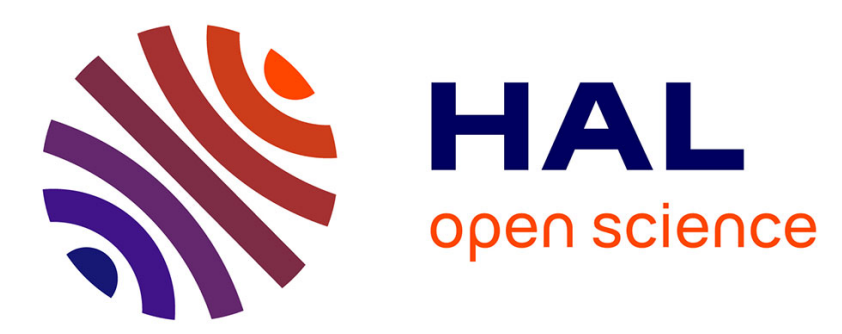

\title{
Are Physicochemical Properties Shaping the Allergenic Potency of Plant Allergens?
}

Joana Costa, Simona Lucia Bavaro, Sara Benedé, Araceli Diaz-Perales, Cristina Bueno-Diaz, Eva Gelencser, Julia Klueber, Colette Larré, Daniel Lozano-Ojalvo, Roberta Lupi, et al.

\section{To cite this version:}

Joana Costa, Simona Lucia Bavaro, Sara Benedé, Araceli Diaz-Perales, Cristina Bueno-Diaz, et al.. Are Physicochemical Properties Shaping the Allergenic Potency of Plant Allergens?. Clinical Reviews in Allergy and Immunology, 2020, 10.1007/s12016-020-08810-9 . hal-03243011

\section{HAL Id: hal-03243011 \\ https://hal.science/hal-03243011}

Submitted on 2 Jun 2021

HAL is a multi-disciplinary open access archive for the deposit and dissemination of scientific research documents, whether they are published or not. The documents may come from teaching and research institutions in France or abroad, or from public or private research centers.
L'archive ouverte pluridisciplinaire HAL, est destinée au dépôt et à la diffusion de documents scientifiques de niveau recherche, publiés ou non, émanant des établissements d'enseignement et de recherche français ou étrangers, des laboratoires publics ou privés. 


\section{Are physicochemical properties shaping the allergenic potency of plant}

\section{allergens?}

Joana Costa ${ }^{1 *}$ (ORCID 0000-0002-8229-2902), Simona Lucia Bavaro ${ }^{2,3}$ (ORCID 0000-00025820-8088), Sara Benedé ${ }^{4}$ (ORCID 0000-0002-9288-9438), Araceli Diaz-Perales ${ }^{5}$ (ORCID 0000-0002-1093-3627), Cristina Bueno-Diaz ${ }^{6}$ (ORCID 0000-0001-7872-8948), Eva Gelencser $^{7}$, Julia Klueber ${ }^{8,9}$, Colette Larré ${ }^{10}$ (ORCID 0000-0001-9585-9536), Daniel LozanoOjalvo $^{11}$ (ORCID 0000-0002-3524-2929), Roberta Lupi ${ }^{10}$ (ORCID 0000-0002-1293-6135), Isabel Mafra ${ }^{1}$ (ORCID 0000-0001-5311-8895), Gabriel Mazzucchelli ${ }^{12}$ (ORCID 0000-00028757-8133), Elena Molina ${ }^{4}$ (ORCID 0000-0001-7918-7768), Linda Monaci ${ }^{2}$ (ORCID 00000001-5650-7909), Laura Martín-Pedraza ${ }^{13}$ (ORCID 0000-0003-3133-0662), Cristian Piras ${ }^{14,15}$, Pedro M. Rodrigues ${ }^{16}$ (ORCID 0000-0002-9668-1204), Paola Roncada ${ }^{17}$, Denise Schrama ${ }^{16}$ (ORCID 0000-0003-0274-5957), Tanja Cirkovic-Velickovic ${ }^{18,19,20}$ (ORCID 0000-0003-25595234), Kitty Verhoeckx ${ }^{21}$ (ORCID 0000-0002-6557-3198), Caterina Villa ${ }^{1}$ (ORCID 00000002-9471-3612), Annette Kuehn ${ }^{8}$ (ORCID 0000-0003-0474-2135), Karin HoffmannSommergruber ${ }^{22}$ (ORCID 0000-0002-8830-058X), Thomas Holzhauser ${ }^{23}$ (ORCID 0000-00027818-7261)

1. REQUIMTE-LAQV/Faculdade de Farmácia Universidade do Porto, Rua de Jorge Viterbo Ferreira 228, 4050-313 Porto, Portugal

2. Institute of Sciences of Food Production (ISPA) - National Research Council (CNR), Bari, Italy

3. Moorepark Food Research Centre, Teagasc, Fermoy, Co. Cork. Ireland

4. Instituto de Investigación en Ciencias de la Alimentación (CIAL), CSIC-UAM, Madrid, Spain

5. Centro de Biotecnologia y Genomica de Plantas (UPM-INIA), Universidad Politecnica de Madrid, Pozuelo de Alarcon, Spain

6. Departmento de Bioquímica y Biología Molecular, Facultad de Ciencias Químicas de la Universidad Complutense de Madrid, Madrid, Spain

7. Department of Biology, Food Science Research Institute, National Agricultural Research and Innovation Centre, Budapest, Hungary

8. Department of Infection and Immunity, Luxembourg Institute of Health, Esch-sur-Alzette, Luxembourg

9. Department of Dermatology and Allergy Center, Odense Research Center for Anaphylaxis, University of Southern Denmark, Odense C, Denmark

10. INRAE, UR 1268 Biopolymers Interactions Assemblies, Nantes, France

11. Precision Immunology Institute. Jaffe Food Allergy Institute. Icahn School of Medicine at Mount Sinai, New York, NY, US

12. Mass Spectrometry Laboratory, MolSys Research Unit, University of Liege, Liege 4000, Belgium

13. Biochemistry and Molecular Biology department, Chemistry Faculty. Complutense University of Madrid, 28040, Madrid, Spain

14. Department of Veterinary Medicine, University of Milan, Italy

15. Department of Chemistry, University of Reading, Whiteknights, Reading RG6 6AD, UK

16. CCMAR, Universidade do Algarve, Campus de Gambelas, Faro, Portugal

17. Department of Health Sciences, University 'Magna Græcia', Catanzaro, Italy

18. University of Belgrade - Faculty of Chemistry, Belgrade, Serbia 
19. Ghent University Global Campus, Yeonsu-gu, Incheon, South Korea

20. Faculty of Bioscience Engineering, Ghent University, Ghent, Belgium

21. Department of Dermatology/Allergology, University Medical Center Utrecht, Utrecht, The Netherlands

22. Department of Pathophysiology and Allergy Research, Medical University of Vienna, Austria

23. Division of Allergology Paul-Ehrlich-Institut, Langen, Germany

\title{
Correspondence:
}

Joana Costa,

Email: jbcosta@ff.up.pt,

Tel: +351 220428500, extension 8842. Fax: +351226093390.

\begin{abstract}
This review searched for published evidence that could explain how different physicochemical properties impact on the allergenicity of food proteins and if their effects would follow specific patterns among distinct protein families. Owing to the amount and complexity of the collected information, this literature overview was divided in two articles, the current one dedicated to protein families of plant allergens and a second one focused on animal allergens.

Our extensive analysis of the available literature revealed that physicochemical characteristics had consistent effects on protein allergenicity for allergens belonging to the same protein family. For example, protein aggregation contributes to increased allergenicity of $2 \mathrm{~S}$ albumins, while for legumins and cereal prolamins, the same phenomenon leads to a reduction. Molecular stability, related to structural resistance to heat and proteolysis, was identified as the most common feature promoting plant protein allergenicity, although it fails to explain the potency of some unstable allergens (e.g. pollen-related food allergens). Furthermore, data on physicochemical characteristics translating into clinical effects are limited, mainly because most studies are focused on in vitro IgE-binding.

Clinical data assessing how these parameters affect the development and clinical manifestation of allergies is minimal, with only few reports evaluating the sensitising capacity of modified proteins (addressing different physicochemical properties) in murine allergy models. In vivo testing of modified pure proteins by SPT or DBPCFC is scarce. At this stage, a systematic approach to link the physicochemical properties with clinical plant allergenicity in real life scenarios is still missing.
\end{abstract}

Keywords: plant allergens, protein families, allergenicity, food processing, matrix effect 
Abbreviations

ATI - $\alpha$-amylase trypsin inhibitors,

BAT - basophil activation test,

DBPCFC - double-blind placebo-controlled food challenge,

EAST - enzyme allergosorbent test,

ELISA - enzyme-linked immunosorbent assay,

GMP - good manufacture practices,

HMW - high molecular weight,

HPP - high pressure processing,

HHP - high hydrostatic pressure,

Immunoglobulin E - IgE

LMW - low molecular weight,

MAT - mast cell activation test,

nsLTP - non-specific lipid transfer proteins,

OAS - oral allergy syndrome,

OFC - open food challenge,

PEF - pulsed electric fields,

PR-10 - pathogenesis-related 10 proteins,

PTM - Post-translational modifications,

PUV - pulsed ultraviolet,

RAST - radioallergosorbent test,

RBL - rat basophilic leukaemia,

S-poor - sulphur-poor,

SPT - skin prick tests,

S-rich - sulphur-rich,

WDEIA - wheat-dependent exercise-induced anaphylaxis,

WHO/IUIS - World Health Organization/International Union of Immunological Societies 


\section{Introduction}

What turns a food protein into an allergen? Why do some proteins act as allergens, while others do not [1]? What are the differences among proteins that increase their intrinsic allergenic potential? Which factors drive sustained tolerance to foods and food proteins? Which immunological events intervene in tolerance breakdown, leading to sensitisation, and most likely subsequent food allergy [2]? The knowledge around the identity of food allergens and how they cluster into protein families has contributed to a better understanding of triggers and cross-reactivity in immunoglobulin $\mathrm{E}$ ( $\mathrm{IgE}$ )-mediated food allergies [3]. However, despite these advances there are still some pivotal questions that remain unanswered $[2,4]$.

In theory, any protein has the potential to elicit an allergic response, but this is not commonly the case [5]. Most allergens belong to a small set of protein families and there are common patterns of biomolecular properties among them. This idea supports that allergens should possess special features and not every protein can become allergenic [6]. Still, not all proteins within a specific family are classified as allergens and there are numerous allergenic proteins that do not present the typical properties associated with their allergenicity [4]. In the case of plants, there are several important groups of allergenic proteins, such as the Prolamin and the Cupin superfamilies.

The effects on physicochemical properties of allergens, such as thermal stability or resistance to proteolysis, have been addressed in order to correlate those characteristics with their impact on the allergenicity (as the ability to induce $\operatorname{IgE}$ production that may mediate clinical reactions) of certain proteins [3,7,8]. Post-translational modifications (PTM), such as glycosylation, hydroxylation or phosphorylation, alter the physicochemical properties of allergens. Protein post-translational glycosylation and process-related glycation seem to play a pivotal role in the allergenic potential of proteins [7-9]. Additionally, other characteristics (e.g. the ability of some proteins to disrupt and cross the intestinal epithelial barrier) have been emphasized as affecting the allergenicity of different proteins, since they are known to facilitate the presentation of food allergens to the immune system $[4,10]$.

Several studies reported on the effect of different physicochemical properties on protein allergenicity, but the overarching picture is still missing. This review is the first of two articles in a thematic compilation (plant and animal allergens) and it is focused on the allergenicity of plant food protein families as affected by different physicochemical parameters.

\section{Plant Allergen Families}

According to the AllFam (Database of Allergen Families) statistics in 2017, there are about 1042 proteins identified as allergens, with $88.4 \%$ (921 proteins) of them being included in the WHO/IUIS (World Health Organization/International Union of Immunological Societies) list of registered allergens $[6,11,12]$. From the total number of allergenic proteins, 959 allergens of all sources (animals, plants, fungi and bacteria) have been assigned to specific families (totalising 151 families of proteins), while 83 molecules have no family classification.

In the specific case of plants, there are about 467 allergens $(95.7 \%$ included in the WHO/IUIS list of allergens, $n=447$ ) and 436 of them being allocated to specific families of proteins $[6,11,12]$. Despite plant allergenic proteins being scattered over 65 families of proteins, more than $44 \%$ (that include most of the relevant plant allergens) belong to eight families: 2S albumins, non-specific lipid transfer proteins (nsLTP), cereal $\alpha$-amylase trypsin inhibitors (ATI) and cereal prolamins (of the Prolamin superfamily), legumins and vicilins (of the Cupin superfamily), profilins and pathogenesis-related (PR)-10 proteins [6,11]. In this review, besides considering the number and importance of the allergens, the criteria for the selection of plant protein families also included some cultural and geographic determinants. For example, it is well known that PR-10 proteins are very relevant and common allergens in regions such as Northern of Europe and Alpine regions, while nsLTP are very important allergens 
among the Mediterranean population (e.g. Spain, Italy) $[13,14]$.

\section{Prolamin Superfamily}

According to recent statistical data, the Prolamin superfamily ranks the first position in terms of total number of allergenic proteins ( 91 identified allergens) $[6,11]$. It is composed by a diverse group of relevant seed storage protein families, like the $2 \mathrm{~S}$ albumins and the cereal prolamins (gliadins and glutenins), as well as, the nsLTP and the ATI $[15,16]$. The members of this superfamily have a large amount of proline and glutamine residues, which is typical for prolamins. Additionally, they share a highly conserved pattern of eight cysteine residues that stabilises their three-dimensional (3D) structure of four $\alpha$-helices that form a righthanded super-helix. Apart from the cysteine skeleton and the $\alpha$-helical structures, these protein families share little sequence homology $[8,16,17]$. The cereal prolamins (gliadins and glutenins) are an exception in the prolamin superfamily concerning their 3D structure. Except for $\omega$-gliadins, they contain $\alpha$-helices and $\beta$-sheets and they are stabilised by disulphide bonds, but due to their low complexity sequence that mainly contain rich interspersed repeats, their final structures are considered to be disordered structures $[18,19]$.

\section{S Albumins}

$2 \mathrm{~S}$ Albumins are one of the major groups of seed storage proteins of the Prolamin superfamily, comprising several allergens identified in peanut, tree nuts, legumes and cereals [12]. They are monomeric proteins between 10 and $18 \mathrm{kDa}$ (Table 1), usually based on two polypeptide chains connected by disulphide bonds [20]. During their synthesis, they undergo proteolytic processing due to the presence of some cleavage points in their sequence (N-terminal signal sequence and connection peptide), leading to a final structure of two subunits, a large subunit of $8-10 \mathrm{kDa}$, and a small one of 3-4 $\mathrm{kDa}$ [21]. Contrarily to most allergenic $2 \mathrm{~S}$ albumins, peanut Ara h 2 occurs as a single polypeptide chain stabilised by disulphide bonds and without a subunit structure [22]. 2S Albumins are encoded by a multigene family, leading to the presence of multiple isoforms. In addition, minor clipping at the $\mathrm{N}$ - and $\mathrm{C}$-terminal of both subunits provides extra variants (e.g. Cor a 14, hazelnut) [23,24].

Allergenic $2 \mathrm{~S}$ albumins show a relatively low sequence identity among plant species, being more conserved among proteins from the same phylogenetic family [25]. Few exceptions of cross-reactivity have been reported, which is the case of Sin a 1 (mustard) with Pin $p 1$ (pine nut) [26], and Act d 13 (kiwi seed) with $2 \mathrm{~S}$ albumins from walnut, peanut and almond [27]. 2S Albumins can present potent allergens, being responsible for triggering severe and systemic adverse immunological responses, as in the case of peanut Ara h 2/Ara h 6 [3].

\section{Nonspecific Lipid Transfer Proteins - nsLTP}

The nsLTP are a large family of proteins that are profuse in all plants, representing as much as $4 \%$ of the total soluble protein fraction. The majority of its members are extracellular proteins associated with cell walls, being mainly accumulated/located at epidermal tissues surrounding the aerial organs (leaves, fruits, stems) [28-30]. The tissue-location of nsLTP has major clinical implications, a fact that is supported by the higher allergenic potency of the peels compared with the pulps of Rosaceae fruits [31]. nsLTP are a frequent cause of food allergy among the adult population, having a high sensitisation prevalence in the Mediterranean area [32,33]. The reasons behind this geographical distribution of food allergy to nsLTP are still unknown, although it might result from primary sensitisation through the airways of homologous pollen allergens in LTP-endemic areas (e.g. olive tree Ole e 7 or oriental plane tree Pla or 3) [14]. Currently, nsLTP-sensitised allergies seems to be increasing in regions outside the Mediterranean area, with recent studies pointing out the importance of nsLTP as primary sensitizers in other European countries, namely in The Netherlands, Austria and the United Kingdom [34-37].

Besides belonging to the Prolamin superfamily, nsLTP are also classified as PR-14 family and their functions are related to in situ modulation 
of lipid composition, signal transduction, vesicular trafficking and lipid transfer $[38,39]$. The nsLTP are small proteins $(9.5-10.5 \mathrm{kDa})$ with very compact and stable 3D structures (Table 1). The folding of the helices results in a tunnel-like hydrophobic cavity along the axis of the molecule, which makes them suitable for binding a wide variety of lipids [40,41]. Differences in lipid-binding affinities of nsLTP might reflect in various immunomodulatory activities $[42,43]$, both by modifying their molecular structure and physicochemical properties, and/or by acting directly on the immune system [44].

nsLTP-induced allergic responses are most often described as severe and systemic (anaphylaxis), although mild symptoms can occur. Peach Pru p 3 is one of the most relevant nsLTP allergens and probably the best studied $[3,36,45]$. More than 42 allergenic nsLTP have been identified in several plant foods, including fruits, vegetables, nuts and cereals, as well as in latex [12]. Owing to their widespread distribution across the plant kingdom, allergenic nsLTP are commonly classified as panallergens, i.e. ubiquitous proteins accountable for the $\mathrm{IgE}$ cross-reactivity to a multiplicity of related and unrelated allergenic sources [46].

\section{Cereal a-amylase trypsin inhibitors (ATI)}

The ATI are proteins present in the endosperm of cereals (wheat, barley, rye, corn and rice seeds), with biological functions of plant defence against parasites, insects, mites and mammalians. Their inclusion in the Prolamin superfamily is due to their high content in glutamine, asparagine and proline residues, as well as, their sequence homology (ranging from 30 to $95 \%$ ) with $2 \mathrm{~S}$ albumins and cereal prolamins $[47,48]$. They are composed by polypeptides of 12-16 kDa with 4-5 disulphide bonds that are essential for their inhibitory activity. Presenting one or more subunits with 120-160 amino acid residues, ATI exist as monomers, dimers or tetramers (Table 1) $[17,48]$.

In wheat, the monomeric $\alpha$-amylase inhibitor 0.28 is named Tri a $15(12 \mathrm{kDa})$, while the homodimers $(24 \mathrm{kDa})$ are often referred as $\alpha$ - amylase inhibitors 0.19 and 0.53 (Tri a 28). The tetrameric proteins $(60 \mathrm{kDa})$ are termed $\mathrm{CM}$ proteins due to their solubility in chloroform/methanol solvent, encompassing Tri a 29 (subunits CM1/CM2), Tri a 30 (CM3), Tri a 40 (subunits CM16/CM17) [12,49]. In wheat, the most abundant ATI are the Tri a 28, followed by Tri a 15 and the Tri a 30 [50]. ATI can sensitise individuals by inhalation or ingestion resulting in occupational allergies like bakers' asthma (wheat, barley and rye) or children atopic dermatitis [51], with clinical symptoms associated with gastrointestinal or cutaneous sensitisation (IgE-mediated food allergy) [52-54]. Tri a 30 (CM3) and Tri a 40 (subunit CM16) have also been reported to be involved in wheat-dependent exercise-induced anaphylaxis (WDEIA) [55].

\section{Cereal prolamins}

The cereal prolamins are the major storage proteins found in the endosperm of cereal grains, being classified as glutenins and gliadins in wheat, secalins in rye and hordeins in barley [17]. They are usually divided in two groups according to their solubility in alcoholwater solutions: gliadins (soluble proteins) and glutenins (insoluble proteins) [56]. None of them was reported to be post-translationally modified. The glutenins are divided in high and low molecular weight (HMW and LMW) subunits, while the gliadin fraction consists of three types of proteins, namely $\alpha / \beta-, \gamma-$ and $\omega-$ gliadins. These cereal prolamins differ in their methionine-cysteine contents and, accordingly, they are categorised in sulphur-poor (S-poor) or sulphur-rich (S-rich) groups [57]. Cereal prolamins from wheat are the best studied, being some of them registered as allergens, namely the gliadins Tri a 19, Tri a 20, and Tri a 21, and the glutenins Tri a 26 and Tri a 36 [12]. Glutenins have polymeric structures, while the gliadins are monomeric proteins, with $\alpha / \beta$-type gliadins showing a compact globular 3Dstructure and $\gamma-/ \omega$-gliadins presenting extended rod-like structures (fibrous proteins) (Table 1) [58]. The S-rich prolamins encompass two types of gliadins ( $\alpha$ - and $\gamma$-types) and LMW subunits of glutenins, which share similar structures with high $\alpha$-helical and low $\beta$-sheet 
contents [59]. These proteins are organised in multi-domains with at least one repetitive proline-rich domain, consisting of blocks of residues. The S-poor prolamins are mostly constituted of $\omega$-gliadins with a repetitive domain (poly-L-proline II and $\beta$-reverse-turn structures) close to the $\mathrm{N}$-terminus of the sequence. When present, the non-repetitive domains are rich in $\alpha$-helices stabilised by disulphide bridges $[19,60,61]$. In wheat-allergic patients, cereal prolamins are able to trigger clinical symptoms that include (among others) urticaria, angioedema, erythema, vomiting, persistent cough, respiratory distress, and in most severe case, anaphylaxis [3]. The $\omega$ gliadins, and notably $\omega-5$ (Tri a 19), are mainly associated with WDEIA (severe food allergy after ingestion plus cofactors such as exercise) in adults [62].

\section{Profilins}

The profilin family occupies the second position in terms of total number of allergenic proteins, with at least 50 plant profilins being identified as important allergens [6,11,12]. Profilins (12-15 kDa cytosolic proteins) are ubiquitous in all eukaryotic cells as highly conserved molecules, sharing sequence identities of $75-85 \%$ among members of distantly related organisms (Table 1) $[46,63,64]$. These proteins participate in the reorganisation of the cytoskeleton, acting as a critical control point in signal transduction from the outer to the inner cell membrane, regulating the intracellular calcium levels and the activity in the microfilament system [65]. Their structures comprise three $\alpha$-helices, seven $\beta$-strands and ten turns that form two hydrophobic cores separated by a central sixstranded $\beta$-sheet [66].

Profilins can bind a variety of physiological ligands: (i) cytoskeletal components, like actin; (ii) polyphosphoinositides, like phosphatidylinositol-4,5-bisphosphate; (iii) proline-rich peptides, like formin-related proteins and vasodilator-stimulated phosphoprotein [67]. Plant profilins may be phosphorylated by MAP kinases for regulation proposes [68]. Profilins are also classified as important panallergens, although the extent of their allergenicity is still a matter of discussion, considering the extreme variability of their clinical expression, which is also dependent on the type of food [14]. Symptoms are, in most cases, mild and limited to oral allergy syndrome (OAS), but there are also reports of severe allergic responses to profilins [3].

\section{Cupin Superfamily}

The cupin superfamily is composed by a wide set of highly diverse protein families across all groups of organisms (including plants and animals), probably sharing a common prokaryotic ancestor [16]. It is the third most important superfamily of plant allergens, with 37 allergenic proteins identified so far $[6,11]$. Members of this superfamily are named as cupins based on their common structural features, namely the presence of a $\beta$-barrel core domain (cupin core) and two short conserved consensus sequence motifs [17]. With two $\beta$ barrel core domains, the bicupins comprise the globulins, which are the major components of the protein fraction of most seeds, legumes and tree nuts. Based on their sedimentation coefficient, globulins are classified as 7/8S and $11 / 12 \mathrm{~S}$, also known as vicilins and legumins, respectively [17].

Globulins have a high clinical relevance, since they are responsible for inducing severe and life-threatening allergic reactions in individuals allergic to legumes (e.g. peanut, lupine, soybean) or to tree nuts (e.g. walnut, hazelnut, almond) [3].

\section{Legumins}

Legumins (11S globulins) represent a major portion of the seed storage proteins $(50-70 \%$ of total protein fraction) in most plants, which aligned with other relevant characteristics contribute to their high importance as class I food allergens [69]. They are multimeric proteins with quaternary structures $(360 \mathrm{kDa})$, occurring as hexamers or as a mix of trimers and hexamers, linked by noncovalent interactions (Table 1) [70,71]. In their tertiary structures, legumins present regions of rigid conformation, as well as sections of mobile assemblies, most likely corresponding to extended loops or unresolved regions [70]. 
Different genes express each monomer as a single primary chain of approximately $60 \mathrm{kDa}$, which is post-translationally cleaved into one acidic and one basic polypeptide with molecular weights of $30-40 \mathrm{kDa}$ and $20 \mathrm{kDa}$, respectively (Table 1), that are held together by disulphide bonds [9,69]. So far, several legumins have been registered as allergens in legumes (peanut Ara h 3, soybean Gly m 6), in tree nuts, such as cashew nut (Ana o 2), walnut (Jug r 4), hazelnut (Cor a 9) and almond (Pru du 6) [12] and more recently also identified in Goji berries [72].

\section{Vicilins}

Like legumins, the vicilins (7S globulins) are seed storage proteins particularly abundant in legumes and tree nuts (representing about 20\% of their protein content depending on the species) (Table 1). They are typically trimeric proteins, though reversible aggregation into hexamers can occur, depending on their ionic strength [70]. Vicilins are large proteins (150$190 \mathrm{kDa}$ ), having two subunits in the range of 40-80 kDa and with a typical subunit of $\sim 50$ $\mathrm{kDa}$ (Table 1). These subunits are frequently glycosylated at one or two N-linked glycosylation sites, positioned at the C-terminal domain [69]. Vicilins present two $\beta$-barrel core domains, but contrarily to legumins, they lack disulphide bonds, being stabilised by noncovalent hydrophobic interactions, hydrogen bonds and van der Waals interactions. Several vicilins have been registered as allergens in legumes, such as peanut (Ara h 1), lupine (Lup an 1) and pea (Pis s 1), in tree nuts (e.g. hazelnut, Cor a 11; walnut, Jug r 2; pistachio, Pis v 3) [12] and more recently also identified in Goji berries [72].

\section{PR-10 proteins}

The pathogenesis related (PR)-10 proteins are an important group of allergens in fruits and vegetables, related to the birch pollenassociated (class II) food allergy. Presently, 29 proteins have been classified as allergenic molecules, 25 of those being registered in the WHO/IUIS list of allergens $[6,11,12]$. PR-10 proteins have a molecular weight of $15-17 \mathrm{kDa}$
(Table 1), are slightly acidic, resistant to proteases and structurally not related to other PR proteins [73-75]. The crystal structure characterisation of a few PR-10 proteins, showed that these proteins have a conserved, highly curved, seven-stranded antiparallel $\beta$ sheet surrounding a long 25 -amino acid $\alpha$-helix (a3) at the C-terminus [76]. Two additional Nterminal short $\alpha$-helices ( $\alpha 1$ and $\alpha 2$ ), located between the $\beta 1$ and $\beta 2$ strands, complete the scaffold creating a hydrophobic core, which works as a ligand-binding site [76,77].

Like others, the PR-10 proteins participate in the defence mechanism of plants, namely in the response to biotic/abiotic stress and in the transport of amphiphilic compounds (fatty acids, cytokines, flavonoids and sterols) through the cellular barrier $[77,78]$. However, some of these proteins are constitutively expressed, indicating a key biological role in plant development. The clinical relevance of these proteins encompass a multitude of different symptoms (ranging from mild to potentially life threatening) with a quick onset (up to few minutes) after the consumption of raw plant foods [3]. In the recent years, a variety of PR-10 proteins and their food homologues causing allergy in humans have been isolated and characterised [79-82]. Bet v 1 is the most representative member of PR-10 proteins, which exists in at least 18 different isoallergens and isoforms [83].

\section{Physicochemical Affecting Allergenicity}

In the attempt to address the question "what turns a food protein into an allergen?" great attention has been devoted to the physicochemical characterisation of food allergens. By now, it is already well established that some physicochemical properties seem to play a major role in the allergenic potential of a protein.

In this review, the selected parameters concerned post-translational modifications, such as glycosylation, phosphorylation and hydroxylation, as well as protein structure and organisational level. Considering that, the majority of foods are commonly consumed after some kind of processing, it was also 
important to understand the protein characteristics which are influenced by processing, such as stability to heat, light/radiation and pressure, as well as, to mechanical and chemical activities.

Accordingly, the parameter of heat stability reflects the influence of different types of food processing with the application of thermal treatments, namely autoclaving, frying, boiling, dry or wet roasting, blanching and baking. Similarly, the effect of glycation and aggregation, which are associated with the use of thermal treatments during food processing were also considered. For the parameter of pressure stability, the effects of high pressure processing (HPP) and high pressure (HP) microfluidisation treatments were analysed, while for light/radiation stability, the information was retrieved from food processes involving gamma-radiation, high voltage impulses, pulsed electric fields (PEF), pulsed ultraviolet (PUV) light and microwave treatments. For mechanical or chemical stabilities, data were collected from the application of sonication and ultrasound treatments or fermentation, alkylation/reduction and enzymatic hydrolysis, respectively. The influence of ligand binding on the allergenic potential of a protein, as well as its potential lipid interactions and the resistance to digestion complete the set of physicochemical parameters that were analysed in this review.

For each plant protein family, literature review on their allergenic members was extensively performed and further described, which can be consulted in detail in the excel file of the supplementary material section (see supplementary material).

\section{Measuring the effect on allergenicity}

Food allergy comprises several immunological mechanisms, although its most common form regards an immediate-type hypersensitivity in which specific $\operatorname{IgE}$ is bound by high-affinity Fce-receptor on the mast cells and basophils of the allergic individuals. Cross-linking of allergen-specific $\operatorname{IgE}$ by the allergen starts a cascade of events, including the release of physiologically active mediators (e.g. histamine) that rapidly lead to biological responses in a number of target tissues [84]. The capacity to bind and cross-link specific IgE is an intrinsic immunological property of the allergenic proteins, which can be monitored by several in vivo and in vitro assays (Table 2).

The presence of IgE in the sera of foodsensitised individuals is not always accompanied by clinical symptoms, therefore assays screening for specific serum $\operatorname{IgE}$ are commonly used as complementary tools for food allergy diagnosis, after proper recording of anamnesis. The immunoblotting is normally used to assess the overall IgE-binding profile of allergens at a qualitative level, while ELISA enable their quantification [85]. Similarly, the radioallergosorbent test (RAST)/enzyme allergosorbent test (EAST)/ImmunoCap allow the quantification of allergen specific IgE levels within human serum/plasma. IgEbinding and functional cross-linking can be tested by ex vivo or in vitro cellular assays, such as human basophil activation test (BAT), mast cell activation test (MAT) and rat basophilic leukaemia (RBL) mediator release assay. In these tests, effector cells are stimulated with allergens (native/recombinant) or extracts and their activation is measured either by mediator release (e.g. histamine, cytokines) or upregulation of cellular surface molecules (e.g. CD63, CD203c) $[85,86]$.

The skin prick tests (SPT) and the food challenges are used for in vivo testing. The first induces specific skin mast cell degranulation after cross-linking of allergen-specific IgE, although its correlation to clinical symptoms is usually restricted to a good negative predictive value [87]. Food challenges, in open (OFC), in closed or in double-blind placebo controlled (DBPCFC) formats, are the best way to confirm allergy. However, these food challenges are burdensome for patients, time consuming, expensive and they can only be performed in specialised medical facilities due to the high risk of severe and systemic allergic reactions during the trial. Moreover, if single allergen components (e.g. peanut Ara h 2) are used for in vivo challenges, those need to be prepared under good manufacture practices (GMP). 
Alternatively, animal models have been proposed to assess the allergenicity (sensitisation and elicitation capacities) of different proteins/foods, namely murine IgEresponse and anaphylaxis.

Most of these assays have been used as excellent tools to evaluate the effect of different physicochemical properties on the IgE-binding capacity of plant food allergens (Table 2). Based on their simplicity and relative low cost, immunoblotting, ELISA and RAST/EAST/immunoCAP, using the serum/plasma from sensitised/allergic subjects, are the first-line assays, being applied to allergens from almost all plant families [88-99]. They are followed by the cellular ex vivo or in vitro cellular assays, which have also been widely employed to study the influence of physicochemical characteristics on protein allergenicity in most plant families [45,91,100125]. Although used at less extent, the SPT and food challenges have been carried out to characterise the allergenicity of proteins as affected by different properties (e.g. denaturation, digestion) $[90,104,107,108,110,111,117,120,121,123,12$ 4,126-132]. The in vivo food challenges, SPT, and even more important, oral food challenges (OFC, DBPCFC) are of high value because of the true human clinical read-out. However, these procedures are difficult to perform, and the availability of test subjects and ethical considerations limit their general application [107,120,121,124,126-130]. Other "functional" tests (BAT, RBL) are considered instead, which seem to have quiet good correlation to the clinical phenotype.

Finally, specific $\operatorname{IgE}$ testing is simpler but limited to the conclusion of "sensitisation" IgEbinding in most cases. Nonetheless, there are some examples, such as the IgE-binding sensitisation to Ara $\mathrm{h}$ 2/6 in peanut allergy or to $\omega 5$-gliadin in WDEIA, that seem to have a good predictive value for clinical reactivity [133]. In most cases, in vitro IgE-binding properties are investigated for the ease of testing, although they usually do not allow for extrapolation to clinical reactivity. Likewise, the in vivo assays using animal models are also less applied to evaluate the allergenic potential of proteins [109,115,123,134-138].

Owing to the complexity of this topic and the heterogeneity of the data collected, it was also important to provide some general definitions and terminology to avoid unnecessary misunderstandings. Herein, some terms were employed following the concepts defined by Verhoeckx et al. [2]. Thus, allergenicity/allergenic potential was used with the meaning of "the potential of a material to cause sensitisation and allergic reactions, frequently associated with IgE", while immunoreactivity refers to "the ability of a material to elicit an immune response" and IgEbinding capacity is "an altered ability of $\operatorname{IgE}$ (also allergenic integrity) to bind to epitopes" [2].

In practice, the terminology of IgE-binding capacity was used for information retrieved from immunoblotting, ELISA and RAST/EAST/immunoCAP assays with the sera of food allergic/sensitised patients, while immunoreactivity was predominantly used to classify data from immunoassays with animal IgG. The terms allergenicity/allergenic potential were mostly used to classified data from assays where an elicitation of an allergic response is induced, namely in mediator release assays (RBL, BAT), in vivo assays (SPT, OFC and DBPCFC) and animal allergy models (mice physiological responses, mice anaphylaxis).

\section{Abundance}

It has been very difficult to establish a correlation between the abundance of an individual allergen in the plant with the risk of sensitisation, mostly due to the scarcity of data on quantitative thresholds for sensitised individuals [139]. Additionally, the few available data in literature can be conflicting. In fact, a recent report stated that no clear correlation could be found between legume protein consumption/allergen concentration and the prevalence of legume sensitisation, as demonstrated for the case study of peanut and soybean allergens [140]. Controversially, it has also been shown that by altering the expression of some allergenic proteins (supressed by RNA 
interference), their IgE-binding capacity is greatly reduced, as described for three major allergens in rice [141,142]. Likewise, the mRNA silencing of Mal d 1 gene lead to a great decrease in the expression of Mal d 1 in the genetically modified apple lines, which enable a drastic reduction, and even complete elimination, of the clinical symptoms in apple allergic patients, as demonstrated by a blindsensory privation oral food challenge [143]. Both perspectives suggest that the amount of allergenic proteins may determine the overall IgE-binding capacity of a food, whereas it seems to be no link between the extent of sensitisation in relation to the amount of allergenic proteins in the diet.

When considering primary sensitisation via ingestion, it is expected that allergens expression at higher levels in a certain food (e.g. cereals) increases the potential for eliciting an allergic reaction in food allergic individuals. This is the case for $2 \mathrm{~S}$ albumins (20-60\% of total protein fraction), legumins (50-70\% of total protein fraction) and vicilins ( $20 \%$ of total protein fraction) (Table 1$)$. As they are major storage proteins in most nuts and other seeds, they make a significant contribution to the human diet, being widely correlated with their high incidence in terms of allergenic molecules capable of inducing adverse immunological responses $[69,144]$. In cereals, prolamins (gliadins and glutenins) are the major fraction of storage proteins, consequently their high content in cereals (e.g wheat) increases the risk of an allergic reaction. The contribution of allergenic cross-reactivity to pollen allergens (e.g. Bet v 1) (primary sensitisation by inhalation) with proteins expressed at moderate or low quantities (e.g. soybean Gly m 4, hazelnut Cor a 1 or celery Api g 1) should not be neglected, because it also increases the risk for inducing allergic responses. Profilins are very relevant allergens, not only due to their high abundance, but also because of their great potential for multiple sensitisation across different plants [145]. The nsLTP are tissue specific proteins [31] and their allergenic potential is well correlated with their abundance, since the removal of nsLTPcontaining tissues significantly decreases the allergenic potential of this family. Additionally, Mal d 3 expression is highly variable among apple cultivars, enabling different allergic responses. Cultivars with low amount of Mal d 3 are less allergenic (as assessed by SPT and DBPCFC) than the ones expressing higher amounts of this allergen [120]. The expression of ATI, nsLTP and the PR-10 protein families is highly dependent on plant cultivar and on environmental conditions [146].

Concluding remarks:

- The high content of $2 \mathrm{~S}$ albumins, legumins, vicilins and cereal prolamins (gliadins and glutenins) in relation to total protein is correlated to increased allergic elicitation risk.

- The abundance of nsLTP is related to increased allergic elicitation risk.

- The abundance (low/high) of the profilins, ATI and PR-10 cannot be correlated to an increased allergenic risk.

\section{Protein structure}

Conformational and/or linear IgE epitopes of proteins play a crucial role in the elicitation of an allergic response [147]. In general, most monomeric allergens are relatively small, stable and with very well organised structures, but some allergenic proteins may form large high-ordered structures (Table 1). There are also some exceptions of unstructured proteins, such as caseins, that act as allergens [148].

Regarding plant food allergens, most molecules have complex structures with a high level of organisation, namely presenting tertiary and quaternary conformations. This is the case of ATI, legumins, vicilins and PR-10 proteins, which present quaternary structures (Table 1) $[48,70,76]$. The loss of high-ordered structure contributes to a decrease in the overall allergenicity of most allergens (Table 3). In contrast, most members from legumins preserve immunogenic subunits (monomers) with IgE-binding capacity (e.g. peanut Ara h 3 and soybean Gly m 6) [71].

2S Albumins, nsLTP, gliadins and profilins are proteins with compact globular structures $[41,58,66,149]$. The loss of protein 3D structures of $2 \mathrm{~S}$ albumin and nsLTP families does not affect their allergenicity [23,126,150], 
while for gliadins and profilins, their allergenic potential is reduced [122,149]. As expected, when the conformational changes occur at the secondary structure level, allergens from legumins, ATI and gliadins exhibit a decrease in their IgE-binding capacity $[136,151]$. Likewise, the alkylation/reduction of $2 \mathrm{~S}$ albumins and gliadins is another factor that reduces their allergenic potential $[23,122,152,153]$, which emphasises the importance of an intact structure that defines a major portion of allergenicity, although in some cases linear epitopes may also impact on allergenicity.

Concluding remarks:

- Destruction of conformation usually leads to:

- Complete loss of allergenicity in food allergens related to inhalant pollen allergen sensitisation (e.g. apple Mal d 1, hazelnut Cor a 1, cherry Pru av 1).

- Partial loss of allergenicity in 2S albumins and LTP as primary sensitizers.

- Partial or minor loss of allergenicity in vicilins and legumins (because of partially intact secondary structured domains and linear epitopes) as primary sensitizers.

- Reduction/alkylation reduces the allergenic capacity of $2 \mathrm{~S}$ albumins and gliadins caused by the destruction of disulphide bonds that are strong stabilisers of protein structure.

- Stability of the protein structure is an important physical chemical characteristic of some allergenic proteins, but it is not a generic allergen characteristic.

\section{Post-translational modifications (PTM)}

PTM occur after translation in the cell and may affect the allergenic potential of proteins (Table 3). Among PTM, protein glycosylation is one of the most relevant and complex processes, consisting of a covalent interaction between a sugar and the side chains of serine and threonine $(\mathrm{O}$-glycosylation) or asparagine $(\mathrm{N}-$ glycosylation) [154]. Glycosylated proteins are considered important mediators in different biological processes, such as protein folding, cell signalling, fertilisation and embryogenesis, but they are also involved in immune activation processes [155]. Hydroxylation and phosphorylation are also PTM of high importance for cellular processes. The first consists of a covalent process involving the addition of a hydroxyl group to the nonnucleophilic functional group of proline, lysine and asparagine, while the second implicates the covalent addition of a phosphate group to the side chain of an arginine, lysine, histidine, tyrosine, serine or threonine residue $[154,156]$. Regarding these PTM (Table 3), glycosylation is commonly referred to as one of the most important physicochemical properties of several allergens. However, besides the glycosylated allergens belonging to the vicilin family [69], only few other glycosylated allergens could be found within plant protein families, namely in legumins (lupine Lup a alpha-conglutin), in $2 \mathrm{~S}$ albumins (stone pine Pin p 1) and in ATI (wheat Tri a 40). In general, the glycosylation of vicilins and wheat Tri a 40 (subunit CM16), has been considered to increase the allergenic potential of these proteins.

The presence of $\mathrm{N}$-glycans in glycoproteins has been positively correlated with increasing human IgE-responses, although their clinical relevance is still a matter of debate. Shreffler et al. [157] demonstrated that peanut Ara h 1, but not its deglycosylated form, activated monocyte-derived dendritic cells as a measure of sensitisation, and by their ability to drive Tcell proliferation. Contrarily, Lauer et al. [158] reported that the presence of $\mathrm{N}$-glycans in hazelnut Cor a 11 did not affect its IgE-binding capacity at the site of elicitation. By now, in the case of vicilins, there is no conclusive evidence that the presence of N-glycans may be associated with increased allergenic responsiveness.

Hydroxylation has been described to increase the elicitation potential of peanut Ara h 2 (2S albumin family) [113]. Phosphorylation can occur in members of the profilin family [68], but no correlation with their allergenic potency has been described so far.

Concluding remarks: 
- Glycosylation can increase the efficiency in the sensitisation capacity of vicilins. No effects for other allergens were found.

- Hydroxylation increased the IgE-binding capacity of peanut Ara h 2 at the site of elicitation. No information was found for other allergens.

- There is no hard evidence for the relation between a PTM (especially glycosylation) and the allergenic potential of a protein. At least for the plant allergens, glycosylation is not a prerequisite for a protein to have a high probability of being an allergen.

\section{Glycation and Aggregation}

Glycation, also referred as Maillard reaction, is a common effect of processing that allow modifying proteins to improve the technological properties of foods, such as solubility, gelling capacity, heat stability, water retention capacity, texture and flavour. The glycation process is a complex form of a nonenzymatic reaction between an available amino group (from proteins) and a carbonylcontaining moiety (usually from a reducing sugar), which normally occurs under mild and safe processing conditions [159]. Besides altering the functional/technological properties of proteins, glycation is also known to affect some biological parameters of food proteins, such as their bioavailability, digestibility and allergenicity. The conformational and biochemical alterations of proteins as a result of glycation may contribute not only to mask existing epitopes, but also to create neoepitopes which are able to activate an IgEresponse [160]. A very typical consequence of conformational changes of proteins, during glycation, is related to the formation of aggregates (complex macrostructures).

For plant families (Table 3), glycation can differently affect proteins at the site of elicitation, although glycated products may also decrease the threshold for allergen sensitisation, comparing to their native counterparts [161]. For example, it has been described to have contradictory effect on the IgE-binding capacity of $2 \mathrm{~S}$ albumins. In the case of peanut Ara h 2, there are reports stating the increased IgE-binding capacity of Ara h 2 glycated products [162], while others describe that the formation of dimers and tetramers of Ara h 2 (aggregated structures) leads to a decrease in its degranulation capacity of mast cells/basophils [100,103,116]. Additionally, heat-processing of peanut seems to be needed for the sensitisation of mice to native Ara h 6, suggesting that complex structures of high molecular weight (between Ara h 6 and Ara h 1) formed during peanut roasting induced the production of IgE specific to native Ara h 6 [163].

In the case of vicilins and nsLTP, Maillard reactions do not seem to affect their elicitation capacity. For vicilins, this fact is also well correlated with the presence of large insoluble aggregates that contribute to maintain their allergenicity. This is the case of hazelnut Cor a 11 and peanut Ara $h$ 1, whose glycation contributed to slightly decrease their IgE/IgGbinding properties, but not the degranulation capacity of basophils. In fact, glycated Cor a 11 and Ara h 1 products increased basophil degranulation capacity $[116,164]$.

Glycation of nsLTP seems to protect the IgEbinding capacity of these proteins by stabilising their conformational structures, as reported for Mal d 3 [119], whose glycation led to the addition of up to four glucose residues attached to Mal d 3 and to a minor reduction (2- to 10fold) in Mal d 3 potency to induce basophil histamine release compared to its native counterpart. A similar outcome was reported for cereal prolamins, whose Maillard products tend to form large aggregates, contributing to a maintain their IgE-binding capacity [89].

Legumins form insoluble aggregates due to glycation, which decreases their IgE-binding capacity, as it was demonstrated for soybean Gly $\mathrm{m} \mathrm{6}$, almond Pru du 6 and tartarian buckwheat Fag t 3 [151,165-167]. The IgEbinding capacity of the majority of the proteins from the PR-10 family decreases in glycated products (cherry Pru av 1) [168]. However, when PR-10 members (peanut Ara h 8) tend to form aggregates due to glycation, their IgEbinding capacity is maintained or even slightly enhanced [169]. 
Some members of the ATI family are naturally aggregated (e.g. wheat Tri a 28), fact that might be strongly correlated with their high IgEbinding frequency among wheat allergic patients $[170,171]$ and high sensitising capacity in murine food allergy model [172]. Regarding profilins, no data describing the effect of glycation and/or formation of aggregates could be found in literature.

Concluding remarks:

- Glycation and aggregation have, in most protein families, similar effects on protein allergenicity.

- Glycation and aggregation decrease the IgE-binding capacity of gliadins, legumins and PR-10 proteins (except for Ara h 8).

- Glycation and aggregation do not affect the IgE-binding capacity of nsLTP and vicilins.

- Glycation has contradictory effects on the IgE-binding of $2 \mathrm{~S}$ albumins, while the formation of aggregates increases their IgE-binding capacity.

\section{Heat stability}

The high stability of allergens towards food processing has been proposed as one of their most pertinent physicochemical characteristics [8]. Heat stability is a parameter of major importance and to evaluate its influence, all conventional thermal treatments (autoclaving, frying, boiling, dry or wet roasting, blanching and baking) applied to allergens of all plant protein families were extensively reviewed. Overall, the heat stability of allergens is well correlated with their allergenicity (Table 3 ).

Members from 2S albumins, nsLTP, cereal prolamins, legumins and vicilins are classified as heat stable allergens. This fact is in good agreement with their high tendency to return to their native state, after being submitted to heat variations, as well as with their high content in conformational epitopes [23,71,89,95]. However, if $\mathrm{pH}$ is changed during heat treatments, proteins might not revert to their native state, such is the case of nsLTP which returns to native state under acidic conditions, but not under neutral ones [150].
In contrast, proteins from PR-10 family are defined as heat-labile, since they are not likely to return to their original folding, highlighting the importance of the conformational epitopes in these allergens. This is the case of celery Api g 1, carrot Dau c 1, apple Mal d 1 and hazelnut Cor a 1, whose allergenicity is significantly reduced or even abolished upon submitted to different heat treatments $[107,124,173,174]$.

Profilins have been considered heat labile, since their presence is commonly associated with raw or minimal processed foods (fruit, vegetables). However, there are also reports of profilins that preserve some IgE-binding capacity after being thermally processed, which is the case of celery Api g 4, tomato Sola 11 and mustard Sin a $4[129,149,175]$. ATI proteins seem to be heat-labile $[88,176]$, although they have also shown evidences of thermal stability [108].

Different heat treatments have distinct effects on the allergenicity of each plant protein family. Boiling/steaming are processes commonly contributing to maintain or reduce the IgE-binding capacity of most allergens ( $2 \mathrm{~S}$ albumins, nsLTP, ATI and vicilins) $[100,114,176,177]$, while roasting has contradictory effects depending on the allergen or allergen family (vicilins and $2 \mathrm{~S}$ albumins). In the specific case of peanut $2 \mathrm{~S}$ albumins (Ara $\mathrm{h}$ 2/Ara $\mathrm{h} \mathrm{6}$ ), roasting has been reported to increase, maintain or even slightly reduce their IgE-binding capacity and ability to elicit histamine release $[103,116,134,178]$. Additionally, most of the severe thermal treatments (e.g. autoclaving) are able to reduce the IgE-binding capacity of several heat-stable allergens, such as nsLTP, legumins and vicilins, as are the examples of apple Mal d 3, cashew nut Ana o 2 and peanut Ara h 3, and peanut Ara $\mathrm{h}$ 1, respectively $[117,119,179,180]$.

Concluding remarks:

- $2 \mathrm{~S}$ Albumins, nsLTP, cereal prolamins, legumins and vicilins are heat stable (high tendency to return to native conformation, depending on the $\mathrm{pH}$ environment). 
- Profilins and PR-10 proteins are heat labile (tendency to suffer irreversible unfolding). ATI have dual behaviour.

- IgE-binding capacity of allergens of most protein families decreased at high temperatures $\left(100^{\circ} \mathrm{C}\right)$ in the presence of water (boiling/steaming), except for nsLTP (no effect).

- IgE-binding capacity of $2 \mathrm{~S}$ albumins, legumins, vicilins and PR-10 proteins increased/decreased (dual behaviour) at very high temperatures (e.g. above $180^{\mathrm{a}} \mathrm{C}$ without the presence of water - roasting).

- IgE-binding capacity decreased for nsLTP, legumins and vicilins upon extreme thermal conditions (e.g. autoclave).

\section{Pressure stability}

Non-thermal treatments, such as those involving the use of high hydrostatic pressure (HHP) or HPP, are faced as innovative food preservation techniques, alternative to conventional thermal treatments [181]. Initially used to inactivate the growth of microorganisms in foods, thereby increasing product shelf life without affecting their quality and flavour, the application of high-pressure (HP) treatments has different effects depending on the food components. In proteins, HP techniques are known to disrupt non-covalent interactions (hydrogen, ionic and hydrophobic bonds), thus affecting their secondary and tertiary structures $[182,183]$. In the recent years, the application of high-pressure technology has gained special attention with respect to the potential effect on the allergenicity of food proteins.

In general, allergens from plant families are typically pressure stable, since the application of HP treatments has no (or very limited) effect on the allergenic potential of nsLTP, profilins, vicilins and PR-10 proteins (Table 3). The application of HP treatments is known to alter the conformation of proteins (secondary and tertiary structures), although there are no evidences of significant modifications on the native state of referred proteins [91,127,184,185].
$2 \mathrm{~S}$ Albumins and legumins are also classified as pressure stable proteins, although some contradictory effects have been reported for both families (Table 3). Within $2 \mathrm{~S}$ albumins, the immunoreactivity of peanut Ara $\mathrm{h} 2$ is decreased by HP microfluidisation [186], while the immunoreactivity of Ara $h 2$ and Ara $h 6$ is not affected by HPP [184]. Likewise, the immunoreactivity of legumins, namely Ses i 6 and Ses i 7 (sesame) is decreased by the application of HP treatments [187], while the IgE-binding capacity of walnut Jug $\mathrm{r} 4$ is not affected by HPP [104]. However, the combination of pressure with other type of treatment (e.g. HPP coupled with heat) has been reported to decrease the allergenic potential of nsLTP, legumins and vicilins, as described for apple Mal d 3, walnut Jug $\mathrm{r} 4$ and peanut Ara h 1, respectively [104,117,188]. Additionally, the combination of autoclave (pressure + heat) with enzymatic hydrolysis also contribute to decrease the IgE-binding capacity of legumins, as reported by cashew nut Ana o 2 and pistachio Pis v 2 and Pis v 5 [96]. Regarding ATI and cereal prolamins, no effect on the application of HP treatments has been reported so far.

Concluding remarks:

- Most plant allergens are pressure-stable (minor changes to protein conformational structure) since pressure processing methods (e.g. HPP) normally contribute to maintain the protein in its native-like state when compared to temperature processing. No data available for members of ATI and cereal prolamin families.

- The IgE-binding capacity of nsLTP, profilins, vicilins and PR-10 is not affected by the application of high pressures, while for $2 \mathrm{~S}$ albumins and legumins, it can be slightly reduced.

- Combination of pressure-heat and pressure-heat-enzymatic hydrolysis treatments are more efficient in reducing the IgE-binding capacity of nsLTP, legumins and vicilins, because pressure change protein at conformational level (3D and 4D structures) making it more 
susceptible to enzyme activity and temperature.

\section{Light/radiation Stability}

Besides HP treatments, other novel nonthermal technologies have been used by the food industry to increase the safety and quality of foods, which include the application of gamma-radiation ( $\gamma$-radiation), PEF and PUV light [182,189]. Treatments, like gammaradiation and UV radiation, are frequently used to increase the storage duration by destroying the surface pathogens present in foods, either by the application of an ionizing radiation (2-7 $\mathrm{kGy}$, medium dosage level) or UV rays (ranging 100-400 nm), respectively [182].

The PEF technology uses short pulses of electricity to inactivate microorganisms, preserving the organoleptic features of foods [190]. The application of microwave radiation (electromagnetic wave) has been widely used for food processing (e.g. thawing of frozen foods, pasteurisation, drying, and pre-cooking). Although being normally classified as a thermal processing technique, microwave radiation has also a non-thermal effect on food proteins [182].

Like in the previous cases, protein stability towards light or radiation treatments also constitutes an important physicochemical parameter of allergens, although the knowledge about their effects is still very limited (Table 3 ). The application of pulsed UV-light significantly reduces the IgE-binding capacity of $2 \mathrm{~S}$ albumins (peanut Ara h 2), legumins (Ara h 3 and soybean Gly m 6) and vicilins (Ara h 1) [191-193]. The effect of gamma-radiation was exploited for legumins, vicilins and profilins, but in all cases, this technology did not induce any alteration in the IgE-binding capacity of sesame Ses i 6 and Ses i 7, cashew nut Ana o 1 or celery Api g 4, respectively $[91,179,194]$.

The allergenic potential of profilins and PR-10 proteins is significantly reduced or even abolished by microwave $\left(100^{\circ} \mathrm{C}, 30 \mathrm{~min}\right)$, as assessed by SPT, mediator release assays and/or EAST, namely in the case of celery Api g 4 and Api g 1, respectively [90,91]. For cereal prolamins (gliadins), their immunoreactivity varies according to the energy applied, increasing to a maximum around $40 \mathrm{~kJ}$ and then gradually returning to its initial level [195]. Microwave heating has no effect on the IgGbinding capacity of $2 \mathrm{~S}$ albumins (cashew nut Ana o 3), legumins (almond Pru du 6 and cashew nut Ana o 2) and vicilins (Ana o 1) $[167,179,196]$. Likewise, microwave heating in combination with ultrasound does not affect the IgE-binding capacity of nsLTP (e.g. peach Pru p 3) [188]. Data on the effect of light/radiation on the allergenicity of ATI is not yet available in the literature.

Concluding remarks:

- The IgE-binding capacity of most plant families is not affected by treatments with radiation (only minor exceptions).

- Exceptions: the IgE-binding capacity is increased in cereal prolamins and decreased in profilins and PR-10 towards microwave radiation.

- $2 \mathrm{~S}$ Albumins, legumins and vicilins are less stable towards light treatments, since their IgE-binding capacity is decreased (by conformational alterations in protein native structure).

\section{Mechanical/chemical stability}

Another non-thermal process commonly used by the food industry is the ultrasound or sonication treatment. This type of food processing applies mechanical waves (20-100 $\mathrm{kHz}$ ) to promote the formation/collapse of bubbles, due to compression and rarefaction phenomena. When the bubbles reach a critical size, they collapse generating local regions of high temperatures and pressures, which subsequently induce protein conformational changes [182].

In general, most allergens present stability towards mechanical processes (e.g. sonication), thus maintaining their allergenicity after being treated with the mechanical processes (Table 3 ). Considering the referred food processing methods, the ultrasound treatment can be applied in combination with other processes (Table 3). However, the information on the effect of ultrasound on the allergenicity of plant protein families is very limited, contributing to maintain or to slightly decrease the IgE-binding capacity of nsLTP (when combined with 
microwave heating) [188] or legumins (when combined with enzymatic hydrolysis and heat), respectively [96].

The application of chemical and enzymatic processes often reduces the allergenicity of several proteins [197]. Among those, the fermentation and enzymatic hydrolysis using different enzymes are considered traditional methods to process foods. The first is a microbial process based on the production of enzymes by the microorganisms, which alters the organoleptic characteristics of the food, contributing to increase its stability and duration [198]. The second uses specific enzymes to disrupt protein structure, thus increasing the added value of food proteins by altering the sensory quality of proteins (modification of food texture and flavour). Additionally, this process is also known to improve the digestibility and nutrient bioavailability of food proteins [199].

The enzymatic hydrolysis can be considered as one of the most effective methods of modifying the allergenicity of food proteins (depending on the type of enzymes used) because it is able to induce the collapse of conformational epitopes and the cleavage of linear ones [182]. Deamidation is one of this processes, which enables the conversion of glutamine and asparagine into glutamic acid and aspartic acid residues, respectively, to increase the solubility of gliadins, by means of chemical processes or enzymatic ones (e.g. transglutaminases) [200]. In general, the enzymatic hydrolysis of proteins from ATI and PR-10 families reduce their IgEbinding capacity (Table 3), as described for brown rice Ory s aA_TI and cherry Pru av 1 [168,201]. For 2S albumins, enzymatic hydrolysis has been described to maintain or decrease their allergenicity [98,102]. In the case of cereal prolamins, their enzymatic hydrolysis with transglutaminase has been reported to increase the IgE-binding capacity of gliadins [132].

The deamidation of gliadins has been reported to present contradictory effects on their allergenicity. On one side, deamidation decreases the IgE-binding capacity of gliadins towards the sera of wheat allergic patients [136], but on the other side, it contributes to an increased severity of the clinical symptoms in patients allergic to deamidated gluten $[121,202,203]$. When allied to other processes (heat, sonication), the enzymatic hydrolysis contributes to the reduction or maintenance of IgE-binding capacity of legumins or profilins, respectively $[96,175]$.

The process of microbial fermentation has only been tested for legumins and vicilins, in the specific case of soybean, which is often consumed in the form of tempeh, miso and yogurt. Microbial fermentation enabled a drastic reduction in the IgE-binding capacity of both Gly $\mathrm{m} 6$ (legumin) and Gly $\mathrm{m} 5$ (vicilin), as well as other allergenic proteins from soybean [204]. Acid fermentation has been tested for profilins and PR-10 proteins, namely for Api g 4 and Api g 1, respectively, contributing to a reduce the IgE-binding capacity of both celery allergens [91].

The use of reducing agents (e.g. sodium sulphite) for food processing is also commonly applied. The treatment of legumins (cashew nut Ana o 2) and $2 \mathrm{~S}$ albumins (peanut Ara h 2, cashew nut Ana o 3) with reducing agents seems to contribute to a significant decrease in their IgE-binding capacity, which might be related to the destruction of allergen conformational epitopes $[97,153]$.

Concluding remarks:

- The stability of proteins is affected by different processing techniques, whereof hydrolysis influences the intactness (integrity) of the proteins and mechanical, heat and pressure change the protein structure (e.g. unfolding).

- Changes in protein structure is seen for nsLTP and legumins (when ultrasound and heat are applied), maintaining or lowering their IgE-binding capacity.

- Changes in protein size (resulting in protein fragmentation, as consequence of fermentation, enzymatic hydrolysis or treatments with reducing agents) normally contributes to maintain or decrease the IgE-binding capacity of $2 \mathrm{~S}$ albumins, ATI, legumins, vicilins, profilins and PR-10.

- Changes in protein size by formation of large aggregates or cross-linked proteins (oxidases), maintains or enhances the IgE- 
binding capacity of cereal prolamins and $2 \mathrm{~S}$ albumins, respectively.

- Deamidation can result in decreased allergenicity of gliadins in wheat allergic patients but increased allergenic potential in deaminated-gluten allergic patients (increased severity of clinical symptoms).

\section{Digestibility and epithelial transport}

Resistance to gastrointestinal digestion may not be a conclusive factor for a protein to be an allergen, since it does not predict whether a protein is likely to be or to become an allergen $[205,206]$. Additionally, in vitro digestion may not be representative of physiological conditions (in vivo digestion), when considering enzyme-to-protein ratios (e.g. pepsin), optimal $\mathrm{pH}$, absence of pancreatin digestion or the presence of co-factors (such as surfactants) and other food components (matrix effect) $[205,206]$. In order to comprehend the allergic response, it is essential to evaluate the influence of digestion on allergens, with special concern to their structural integrity and subsequent capacity to prompt T-cell differentiation and IgE-mediated activation of effector cells upon gastrointestinal uptake [85]. Regarding plant food allergens (Table 3), most of the studies evaluate the effect of digestion on allergens using pure proteins or extracts, whereas only very few include or use the whole food [109,207-209]. The profilins and PR-10 proteins are critically affected by the gastrointestinal digestion, being totally degraded during the process, which can lead to a severe reduction, or even to the elimination of their IgE-binding capacity. This is the case of profilins, such as mustard Sin a 4, apple Mal d 4, melon Cuc $\mathrm{m} 2$ and cherry Pru av 4 [118,149,210-212]. Likewise, the simulated gastrointestinal degradation of PR-10 proteins, such as apple Mal d 1, celery Api g 1 and hazelnut Cor a 1 , revealed that these proteins were completely fragmented after a few minutes of exposure to pepsin [106,213,214]. This is well correlated to the fact that both families of proteins are classified as class 2 food allergens [215], which are normally responsible for triggering mild clinical symptoms, often limited to the OAS.
Members of the $2 \mathrm{~S}$ albumins (Brazil nut Ber e 1 , peanut Ara h 2, mustard Sin a 1 and hazelnut Cor a 14), ATI and cereal prolamins are highly resistant to proteolysis, allowing only partial degradation, thus contributing to the preservation of their IgE-binding capacity $[23,89,93,109,112,149,152,216]$. Proteins of the nsLTP family are also able to preserve their allergenicity since they are only partially digested, although their resistance to proteolysis is highly influenced by the type of lipid-ligand associated with each allergen [42,110].

2S Albumins, nsLTP, cereal prolamins and vicilins partially maintain some structural integrity after digestion, thus facilitating their involvement in transcellular mechanisms that allow them to cross the epithelium barrier in their native state, which greatly contribute to increase their allergenic potential [10,45,102,112,217-219]. This is well related to the fact that these protein families are classified as potent class 1 food allergens, being capable of primary sensitisation and induction of moderate to severe clinical symptoms in allergic individuals.

When compared to vicilins, legumins are slightly less resistant to proteolysis, suffering partial degradation after the gastrointestinal digestion. Legumins are more degraded by pepsin activity than by trypsin, leading to a small decrease in their IgE-binding capacity [71,105,180,220,221]. However, legumins are highly organised structures, presenting immunogenic subunits even after digestion, thus contributing to partially retain their allergenic potential.

Concluding remarks:

- Profilins and PR-10 proteins are rapidly degraded by pepsin during gastric digestion, drastically reducing or even eliminating their IgE-binding capacity.

- $2 \mathrm{~S}$ Albumins, nsLTP, ATI, cereal prolamins, legumins and vicilins are strongly resistant to proteolysis, with only partial degradation after complete gastrointestinal digestion. All these proteins tend to preserve their allergenicity after passing the digestion process. 
- $2 \mathrm{~S}$ Albumins, nsLTP, cereal prolamins and vicilins basically preserve their structural integrity after digestion, allowing them to cross the epithelium barrier (by transcellular mechanisms) in a native state and increasing their allergenic potential.

\section{Ligand/Lipid binding and interactions}

Among their physicochemical properties, several food allergens are also capable of binding ligands, such as metal ions and lipids, which is known to enhance their thermal and proteolytic stability [9]. Some plant food allergens occur naturally as lipid-protein complexes, such as the nsLTP that are structurally prepared to transport lipids in their hydrophobic cavity. Owing to this characteristic, nsLTP are more resistant to thermal processing and to proteolytic activity, thus contributing to preserve their allergenicity (Table 3) [110].

Besides nsLTP, there are two proteins from the $2 \mathrm{~S}$ albumin and PR-10 families, namely the Brazil nut Ber e 1 and peanut Ara $h$ 8, respectively, which present hydrophobic regions capable of binding lipids [135,169]. Like for the nsLTP, lipid-binding allows these two allergens to maintain some IgE-binding capacity upon processing and digestion. Additionally, the interaction between Ber e 1 and its lipid-ligand increases the sensitisation capacity of this allergen [135].

Along with lipid-binding capacity of some allergens, the interactions between lipids and proteins have also been highlighted as very relevant factors in the elicitation of an allergic response. Lipid-protein interactions can modify the digestion of the allergen within the gastrointestinal tract, aiding their passage through the intestinal epithelial barrier, thus influencing the allergenic potential of a protein [43].

The interaction of legumins and vicilins with lipids protect these proteins from enzymatic degradation, enabling to preserve their structural integrity and subsequently contributing to maintain their allergenicity (Table 3), which has been described for Sin a 2 (mustard legumin) and Ara h 1 (peanut vicilin)
[105]. Similarly, in the case of $2 \mathrm{~S}$ albumins (mustard Sin a 1) and PR-10 proteins (apple Mal $\mathrm{d} 1$ and birch pollen Bet $\mathrm{v}$ 1), the presence of lipids seems to preserve the integrity of the molecules upon digestion, thus conserving or even slightly increasing their allergenicity $[149,222]$. These data are well correlated with some recent studies reporting that lipids can act as adjuvants, stimulating the innate immunity followed by improved allergen-specific immune responses when used in combination with a specific allergen [43].

Concluding remarks:

- Lipid binding propensities of nsLTP and two proteins: Brazil nut Ber e 1 (2S albumin) and peanut Ara h 8 (PR-10).

- Allergens (nsLTP, Ber e 1 and Ara h 8) that interact with their lipid-ligands show molecular stability against food processing and (duodenal) digestion.

- Increased stability towards foodtechnological processing and digestion leads to preservation of the IgE binding capacity of nsLTP, Ber e 1 (2S albumin) and Ara h 8 (PR-10).

- The presence of lipids during protein digestion has a protecting effect on the proteolysis of proteins, contributing to maintain or even increase the IgEbinding capacity of $2 \mathrm{~S}$ albumins, legumins, vicilins and PR-10 proteins.

\section{Can Physicochemical Properties Shape Allergenicity?}

Food allergens were previously defined as small in size (10-70 kDa), with globular conformation, often glycosylated and resistant to heat, low $\mathrm{pH}$ and enzymatic activity $[223,224]$. However, despite the commonly accepted concept that allergens conserve a certain pattern of specific physicochemical properties, this might not always be true. In fact, with the increasing number of proteins that has been identified and classified as food allergens, there are several important allergens that do not fit into this general classification (Tables 2-4). So, at this stage, is it possible to establish straightforward correlations between specific physicochemical properties and their 
impact on protein allergenicity? Or should this concept be carefully revised?

According to the tendencies observed in our analysis, the impact that each physicochemical property has on protein allergenicity is summarised in Table 4. In most cases, independent effects of distinct physicochemical proteins often result in a common pattern, which relates to the preservation of protein structural integrity.

In the universe of food allergenic proteins, some are glycosylated, but this PTM is not always synonym of increased allergenicity. Among the most relevant families of plant proteins, glycosylation is not a common feature of allergenicity, since only vicilins and three other proteins (stone pine Pin $\mathrm{p} \mathrm{1,} \mathrm{lupine} \mathrm{Lup} \mathrm{a}$ alpha-conglutin and wheat Tri a 40) are glycosylated. Nonetheless, in those cases, glycosylation contributes to enhance their IgEbinding capacity.

Small proteins with globular structure are more stable to external interactions, but there are plenty examples of potent allergens that present high molecular weight $(>70 \mathrm{kDa})$ and high level of structural organisation (quaternary structure), such as vicilins and legumins. Still, the loss of secondary structures and the destruction of disulphide bonds normally contribute to reduce the allergenicity of most proteins, which means that protein structure is an important physicochemical parameter.

Protein stability towards heat could be considered a physicochemical parameter that potentially shape the allergenicity of plant allergens, since most potent food allergens are heat-stable (e.g. 2S albumins, vicilins). However, this property fails to explain why many heat-labile proteins are highly relevant food allergens (e.g. profilins, PR-10 proteins). In this context it is also important to emphasise that profilins and PR-10 allergens in fruits and vegetables are usually allergenic because they are ingested as raw or weakly processed foods, which means that proteins are still in their native shape. This type of allergy is usually restricted to the oral cavity (OAS), although reports of symptoms with increased severity have also been described [94,225].
Protein resistance towards proteolytic activity (enzymatic hydrolysis, chemical hydrolysis or fermentation) could be positively correlated with allergenic potential, although with different expected outcomes. The breakdown of protein in small size peptides (strategy followed for the production of hypoallergenic foods) normally contributes to mitigate peptide allergenicity, while enzymatic cross-linking of proteins can contribute for the opposite effect (e.g. cereal prolamins) (Table 4) [132,137].

Protein resistance to digestion process, especially pepsin resistance, cannot be considered as good predictor for allergenicity, once it fails to explain the existence of potent pepsin-labile allergens, such as peanut Ara h 3 (legumin,) and soybean Gly m 6 (legumin) [71]. The way allergenic proteins interact with lipids during the digestion process might contribute to conserve their allergenic potential, since lipids may stabilise proteins and thus preserve structure related allergenicity.

It is also important to stress that it is very difficult to determine how protein changes affect the development or clinical manifestations of food allergies in real-life scenarios. Ethical reasons and limitations in monitoring the molecular changes of allergens in real-life processed food matrices, and subsequent processing in humans, highlight the currently unmet needs faced in the food allergy field. The few studies that evaluate the sensitising capacity of modified proteins are mostly performed in murine allergy models. For instance, Bellinghausen et al. [172] used a humanised murine allergy model to assess allergen-induced gut inflammation. The authors concluded that allergen-specific human $\operatorname{IgE}$ was greatly enhanced in mice on wheat ATIcontaining diet than in mice on gluten-free diet. Accordingly, ATI were considered as key sensitizers of wheat allergy and that these proteins can be used in nutritional therapeutic strategies to address allergen- and gluteninduced intestinal and extraintestinal inflammation [172]. Likewise, Denery-Papini et al. [121] and Gourbeyre et al. [123] reported that, despite different sensitisation paths (oral and intraperitoneal), deamidated gliadins were much more competent than native gliadins in 
inducing allergic sensitisation in mice, and subsequently, in triggering a more severe elicitation phase. Mirotti et al. [135] also described that lipids were necessary for the sensitisation of mice to Ber e 1 (Brazil nut).

Studies carrying out SPT or DBPCFC are rare, mostly due to all ethical issues associated with it. SPT are normally conducted using whole protein extracts [95,104,117,124,126-128], whose results require further verification by performing oral food provocation. In addition, appropriate analytical methods are required to understand the physicochemical changes in the food allergens. The combination of analytical and clinical characterisation may allow drawing conclusions about the impact of physicochemical parameters on protein allergenicity with regard to clinical manifestation.

However, very few SPT have been performed with modified proteins, such as the case of the work described by Sancho et al. [119] and Vassilopoulou et al. [110], where purified native versus heat Mal d $3\left(100^{\circ} \mathrm{C}, 60 \mathrm{~min}\right)$ and purified native versus digested Vit $\mathrm{V} 1$, respectively, were used to assess the effects of thermal processing or enzymatic hydrolysis on the allergenicity of tested proteins. Likewise, Denery-Papini et al. [121] and Palosuo et al. [132] tested natural versus deaminated gluten and native versus transglutaminase crosslinked Tri a 19, respectively, by SPT to evaluate the effect of chemical hydrolysis and enzymatic cross-linking on the allergenicity of specific wheat proteins.

DBPCFC is normally conducted using the whole allergenic food blinded within a complex food matrix and the outcome of a food challenge is correlated with the specific allergenic food. As example, a DBPCFC was carried out in humans using raw wheat flour and deamidated gluten in a stewed apple, where authors concluded that deamidated gluten could induce sensitisation to deamidated gliadins in wheat tolerant individuals [121].

\section{Conclusions}

The data collected from all the reported studies present a huge variability, being normally defined at a qualitative level, which increases the complexity of the analysis presented in this review. It became clear that our knowledge provided by the literature still presents numerous gaps.

One of these major gaps concerns the lack of harmonised protocols since each study is conducted in different conditions. The use of different immunoassays, different sources of patients' sera (affected by geographical differences, age, sex, presence of other diseases, genomic heritage, among others), sera or plasma, and the use of pure protein, pure extracts or matrix, are just some examples among the numerous variables that must be considered when conducting this type of studies. Additionally, most information come from studies evaluating the IgE-binding capacity of allergenic proteins as affected by different parameters, rather than from functional assays, DBPCFC or sensitisation tests, thus hampering their correct correlation with real clinical outcomes.

Another important gap, concerns the lack of studies evaluating simultaneously the impact of such physicochemical proteins in non-allergens and allergens of the same family, or even of the same type [205,226]. Studying the physicochemical properties of allergens can be faced as the fundamental background for better understanding food allergy and subsequently for developing a better allergenicity assessment of food proteins.

The exact role that each parameter has on the allergenicity of different types/families of plant food allergens is not yet fully understood. Within each protein family of plant foods, their allergenic members seem to follow the same tendency, although occasional exceptions can be observed. At individual basis, some parameters like heat stability, resistance to proteolytic activity and structural stability are considered of vital importance for protein allergenicity. However, since most of the methods used for allergenicity assessment are made indirectly, there is still a significant gap between the influence of each physicochemical parameter and their real clinical impact. Ideally, the impact of processing should be assayed in vivo in humans using food grade preparations. Therefore, in order to study the 
molecular characteristics in detail, the allergens would need to be prepared (extracted, purified) from the food grade material, which can result in a hard task (difficult and prone to bias), since usually only native-like structures are extracted. Consequently, other immunoreactive and bioavailable structures might be neglected due to the fact of being insoluble under the conditions of experimental investigation. By contrast, one must consider that working on single allergens, processed under lab conditions might help to better characterise allergens at the molecular level, although this experimental setting might not fully reflect the in vivo reality. Moreover, for human in vivo studies, such food grade material would need to be prepared under good manufacture practice conditions. There is also the debate about using animal models to predict the allergenicity, but there is still a certain degree of uncertainty to which extend the findings can be extrapolated to the human condition.

In summary, several physicochemical parameters have been described in the scientific literature that can explain their impact on plant protein allergenicity (Figure 1). Especially parameters that support protein structure integrity are of importance. Despite observed tendencies within conserved protein families of plant food allergens, several exemptions exist at the level of individual allergens. Hence, we are likely able to explain allergenicity for many of the identified plant food allergens, especially at the site of symptom elicitation. However, using this information for allergenicity prediction of novel proteins or in relation to food processing parameters remains a future challenge. Moreover, the knowledge about physicochemical parameters that influence sensitisation is scarce and requires further attention in food allergen research.

\section{Acknowledgements}

The authors are all part of the COST Action FA1402 entitled ImpARAS - Improving Allergy Risk Assessment Strategy for New Food Proteins. The authors thank all ImpARAS members for their active participations of the ImpARAS meetings and lively discussions.

\section{Funding}

Authors highly appreciate the support from the COST Office. This article is based upon work from COST Action FA1402, supported by COST (European Cooperation in Science and Technology, www.cost.eu). This work was also supported by Fundação para a Ciência e Tecnologia under the Partnership Agreement UIDB 50006/2020 and by the projects AlleRiskAssess - $\quad$ PTDC/BAAAGR/31720/2017 and NORTE-01-0145FEDER-00001. C.V. is grateful to FCT grants (PD/BD/114576/2016) financed by POPHQREN (subsidised by FSE and MCTES). T.C.V. is grateful to the Ministry of Education, Science and Technological Development of the Republic of Serbia through grant number OI172024. P.M.R. and D.S. are grateful to FCT through project UIDB/04326/2020 and Mar2020 16-02-01-FMP-0014 - "ALLYFISH". J.K. and A.K. acknowledge the PRIDE program grant (PRIDE/11012546/NEXTIMMUNE) by the Fonds National de la Recherche (FNR), Luxembourg and a translational grant (APSIS, PMC/2017/02) by the Personalised Medicine Consortium (PMC), Luxembourg.

\section{Authors Contributions}

All authors contributed to the study conception, design, data collection and analysis. All authors have taken part in the discussions and writing of the article. All authors read and approved the final manuscript.

\section{Supplementary material}

Data from the extensive literature review on each protein family and their allergenic members is fully described/summarised in the supplementary material section, as an excel file. This excel file is divided in 8 pages, each dedicated to a single protein family (2S albumins, nsLTP, ATI, cereal prolamins, profilins, legumins, vicilins and PR-10 proteins). All the abbreviations used in the excel file are presented in this manuscript as an abbreviation list. Based on the information gather in this excel file, Table 3 was constructed, thus summarising the data 
presented in the supplementary material section.

\section{Compliance \\ with \\ Ethical \\ Standards \\ Declaration of conflicts}

All authors declare no conflict of interests.

\section{References}

1. Aas K (1978) What makes an allergen an allergen. Allergy 33:3-14. https://doi.org/10.1111/j.1398-9995.1978.tb01501.x

2. Verhoeckx KCM, Vissers YM, Baumert JL, Faludi R, Feys M, Flanagan S, Herouet-Guicheney C, Holzhauser T, Shimojo R, van der Bolt N, Wichers H, Kimber I (2015) Food processing and allergenicity. Food Chem Toxicol 80:223-240. https://doi.org/10.1016/j.fct.2015.03.005

3. Matricardi PM, Kleine-Tebbe J, Hoffmann HJ, Valenta R, Hilger C, Hofmaier S, Aalberse RC, Agache I, Asero R, Ballmer-Weber B, Barber D, Beyer K, Biedermann T, Bilò MB, Blank S, Bohle B, Bosshard PP, Breiteneder H, Brough HA, Caraballo L, Caubet JC, Crameri R, Davies JM, Douladiris N, Ebisawa M, EIgenmann PA, Fernandez-Rivas M, Ferreira F, Gadermaier G, Glatz M, Hamilton RG, Hawranek T, Hellings P, Hoffmann-Sommergruber K, Jakob T, Jappe U, Jutel M, Kamath SD, Knol EF, Korosec P, Kuehn A, Lack G, Lopata AL, Mäkelä M, Morisset M, Niederberger V, Nowak-Węgrzyn AH, Papadopoulos NG, Pastorello EA, Pauli G, Platts-Mills T, Posa D, Poulsen LK, Raulf M, Sastre J, Scala E, Schmid JM, Schmid-Grendelmeier P, Hage M, Ree R, Vieths S, Weber R, Wickman M, Muraro A, Ollert M (2016) EAACI Molecular Allergology User's Guide. Pediatr Allergy Immunol 27:1-250. https://doi.org/10.1111/pai.12563

4. Scheurer S, Toda M, Vieths S (2015) What makes an allergen? Clin Exp Allergy 45:1150-1161. https://doi.org/10.1111/cea.12571

5. Masilamani M, Commins S, Shreffler W (2012) Determinants of Food Allergy. Immunol Allergy Clin North Am 32:11-33. https://doi.org/10.1016/j.iac.2011.12.003

6. Radauer C, Bublin M, Wagner S, Mari A, Breiteneder H (2008) Allergens are distributed into few protein families and possess a restricted number of biochemical functions. J Allergy Clin Immunol https://doi.org/10.1016/j.jaci.2008.01.025

7. Pekar J, Ret D, Untersmayr E (2018) Stability of allergens. Mol Immunol

100:14-20. https://doi.org/10.1016/j.molimm.2018.03.017

8. Breiteneder H, Mills ENC (2005) Plant food allergens - structural and functional aspects of allergenicity. Biotechnol Adv 23:395399. https://doi.org/10.1016/j.biotechadv.2005.05.004

9. Breiteneder H, Mills ENC (2005) Molecular properties of food allergens. J Allergy Clin Immunol 115:14-23. https://doi.org/10.1016/j.jaci.2004.10.022

10. Price D, Ackland ML, Suphioglu C (2017) Identifying epithelial endocytotic mechanisms of the peanut allergens Ara $\mathrm{h} 1$ and Ara $\mathrm{h}$ 2. Int Arch Allergy Immunol 172:106-115. https://doi.org/10.1159/000451085

11. The Database of Allergen Families, Medical University of Vienna, Vienna, Austria (2020) http://www.meduniwien.ac.at/allfam/. Accessed 6 April 2020

12. World Health Organization/International Union of Immunological Societies (WHO/IUIS) Allergen Nomenclature Sub-committee (2020) http://www.allergen.org/. Accessed 31 March 2020

13. Andersen M-BS, Hall S, Dragsted LO (2009) Identification of European allergy patterns to the allergen families PR-10, LTP, and profilin from Rosaceae fruits. Clin Rev Allergy Immunol 41:4-19. https://doi.org/10.1007/s12016-009-8177-3

14. Asero R, Piantanida M, Pinter E, Pravettoni V (2018) The clinical relevance of lipid transfer protein. Clin Exp Allergy 48:6-12. https://doi.org/10.1111/cea.13053
15. Shewry PR, Halford NG (2002) Cereal seed storage proteins: structures, properties and role in grain utilization. J Exp Bot 53:947-958. https://doi.org/10.1093/jexbot/53.370.947

16. Radauer C, Breiteneder H (2007) Evolutionary biology of plant food allergens. J Allergy Clin Immunol 120:518-525. https://doi.org/10.1016/j.jaci.2007.07.024

17. Breiteneder H, Radauer C (2004) A classification of plant food allergens. J Allergy Clin Immunol 113:821-830 https://doi.org/10.1016/j.jaci.2004.01.779

18. Tatham AS, Field JM, Smith SJ, Shewry PR (1987) The conformations of wheat gluten proteins, II, aggregated gliadins and low molecular weight subunits of glutenin. J Cereal Sci 5:203-214. https://doi.org/10.1016/S0733-5210(87)80023-1

19. Tatham AS, Shewry PR (1985) The conformation of wheat gluten proteins. The secondary structures and thermal stabilities of $\alpha-, \beta$ $\gamma$ - and $\omega$-gliadins. J Cereal Sci 3:103-113 https://doi.org/10.1016/S0733-5210(85)80021-7

20. Pastorello EA, Pravettoni V, Trambaioli C, Pompei C, Brenna O, Farioli L, Conti A (2001) Lipid transfer proteins and 2S albumins as allergens. Allergy 56:45-47. https://doi.org/10.1034/j.13989995.2001.00914.x

21. Shewry PR, Napier JA, Tatham AS (1995) Seed storage proteins: structures and biosynthesis. Plant Cell 7:945-956. https://doi.org/10.1105/tpc.7.7.945

22. Lehmann K, Hoffmann S, Neudecker P, Suhr M, Becker W-M, Rösch P (2003) High-yield expression in Escherichia coli, purification, and characterization of properly folded major peanut allergen Ara $\mathrm{h}$ 2. Protein Expr Purif 31:250-259. https://doi.org/10.1016/S1046-5928(03)00190-6

23. Pfeifer S, Bublin M, Dubiela P, Hummel K, Wortmann J, Hofer G, Keller W, Radauer C, Hoffmann-Sommergruber K (2015) Cor a 14 , the allergenic $2 \mathrm{~S}$ albumin from hazelnut, is highly thermostable and resistant to gastrointestinal digestion. Mol Nutri Food Res 59:2077-2086. https://doi.org/10.1002/mnfr.201500071

24. Korte R, Happe J, Brümmer I, Brockmeyer J (2017) Structural characterization of the allergenic $2 S$ Albumin Cor a 14: Comparing proteoform patterns across hazelnut cultivars. J Proteome Res 16:988-998. https://doi.org/10.1021/acs.jproteome.6b00924

25. Monsalve RI, Villalba M, Rodríguez R (2001) Allergy to mustard seeds: the importance of $2 \mathrm{~S}$ albumins as food allergens. Internet Symposium on Food Allergens 3:57-69. http://www.foodallergens.de/

26. Bueno C, Martin-Pedraza L, Cuesta-Herranz J, Villalba M (2016) Is the cross-reactivity of $\mathrm{Sin}$ a $1,2 \mathrm{~S}$ albumin from mustard seeds, exclusively restricted to Brassicaceae members? JSM Allergy Asthma 1:1001. https://www.jscimedcentral.com/Allergy/allergy1-1001.pdf

27. Sirvent S, Cantó B, Gómez F, Blanca N, Cuesta-Herranz J, Canto G, Blanca M, Rodríguez R, Villalba M, Palomares O (2014) Detailed characterization of Act $\mathrm{d} 12$ and Act d 13 from kiwi seeds: implication in IgE cross-reactivity with peanut and tree nuts. Allergy 69:1481-1488. https://doi.org/10.1111/all.12486

28. Salcedo G, Sanchez-Monge R, Barber D, Diaz-Perales A (2007) Plant non-specific lipid transfer proteins: an interface between plant defence and human allergy. Biochim Biophys Acta - Mol $\begin{array}{llllll}\text { Cell } & \text { Biol } & \text { Lipids } & 1771: 781 & \text { - } & 791 .\end{array}$ https://doi.org/10.1016/j.bbalip.2007.01.001

29. Marzban G, Puehringer H, Dey R, Brynda S, Ma Y, Martinelli A, Zaccarini M, van der Weg E, Housley Z, Kolarich D, Altmann F, Laimer M (2005) Localisation and distribution of the major allergens in apple fruits. Plant Sci 169:387-394. https://doi.org/10.1016/j.plantsci.2005.03.027

30. Ahrazem O, Jimeno L, López-Torrejón G, Herrero M, Espada JL, Sánchez-Monge R, Duffort O, Barber D, Salcedo G (2007) Assessing allergen levels in peach and nectarine cultivars. Ann Allergy Asthma Immunol 99:42-47. https://doi.org/10.1016/S1081-1206(10)60619-9

31. Zuidmeer L, van Ree R (2007) Lipid transfer protein allergy: primary food allergy or pollen/food syndrome in some cases. Curr Opin Allergy Clin Immunol 7:269-273. https://doi.org/10.1097/ACI.0b013e32814a5401

32. Fernández-Rivas M, González-Mancebo E, Rodríguez-Pérez R, Benito C, Sánchez-Monge R, Salcedo G, Alonso MD, Rosado A, Tejedor MA, Vila C, Casas ML (2003) Clinically relevant peach allergy is related to peach lipid transfer protein, Pru p 3 , in the 
spanish population. J Allergy Clin Immunol 112:789-795. https://doi.org/10.1016/S0091-6749(03)02016-5

33. Schulten V, Nagl B, Scala E, Bernardi ML, Mari A, Ciardiello MA, Lauer I, Scheurer S, Briza P, Jürets A, Ferreira F, Jahn-Schmid B, Fischer GF, Bohle B (2011) Pru p 3, the nonspecific lipid transfer protein from peach, dominates the immune response to its homolog in hazelnut. Allergy 66:1005-1013. https://doi.org/10.1111/j.13989995.2011.02567.x

34. Skypala IJ, Cecchi L, Shamji MH, Scala E, Till S (2019) Lipid Transfer Protein allergy in the United Kingdom: Characterization and comparison with a matched Italian cohort. Allergy 74:13401351. https://doi.org/10.1111/all.13747

35. Decuyper II, Pascal M, Van Gasse AL, Mertens C, Díaz-Perales A, Araujo G, Torradeflot M, Rius J, Balsells S, Muñoz-Cano RM, Bartra J, Li L, Sabato V, Hagendorens MM, Bridts CH, De Clerck LS, Ebo DG, Faber MA (2020) Performance of basophil activation test and specific IgG4 as diagnostic tools in nonspecific lipid transfer protein allergy: Antwerp-Barcelona comparison. Allergy 75:616-624. https://doi.org/10.1111/all.14040

36. Mothes-Luksch N, Raith M, Stingl G, Focke-Tejkl M, RazzaziFazeli E, Zieglmayer R, Wöhrl S, Swoboda I (2017) Pru p 3, a marker allergen for lipid transfer protein sensitization also in Central Europe. Allergy 72:1415-1418. https://doi.org/10.1111/all.13151

37. Gaier S, Oberhuber C, Hemmer W, Radauer C, Rigby NM, Marsh JT, Mills CEN, Shewry PR, Hoffmann-Sommergruber K (2009) Pru p 3 as a marker for symptom severity for patients with peach allergy in a birch pollen environment. J Allergy Clin Immunol 124:166-167. https://doi.org/10.1016/j.jaci.2009.02.023

38. Liu F, Zhang X, Lu C, Zeng X, Li Y, Fu D, Wu G (2015) Nonspecific lipid transfer proteins in plants: presenting new advances and an integrated functional analysis. J Exp Bot 66:5663-5681. https://doi.org/10.1093/jxb/erv313

39. Fairn GD, McMaster CR (2008) Emerging roles of the oxysterolbinding protein family in metabolism, transport, and signaling. Cell Mol Life Sci 65:228-236. https://doi.org/10.1007/s00018007-7325-2

40. Edqvist J, Blomqvist K, Nieuwland J, Salminen TA (2018) Plant lipid transfer proteins: are we finally closing in on the roles of these enigmatic proteins? J Lipid Res 59:1374-1382. https://doi.org/10.1194/jlr.R083139

41. Salminen TA, Blomqvist K, Edqvist J (2016) Lipid transfer proteins: classification, nomenclature, structure, and function. Planta 244:971-997. https://doi.org/10.1007/s00425-016-2585-4

42. Abdullah SU, Alexeev Y, Johnson PE, Rigby NM, Mackie AR, Dhaliwal B, Mills ENC (2016) Ligand binding to an allergenic lipid transfer protein enhances conformational flexibility resulting in an increase in susceptibility to gastroduodenal proteolysis. Sci Rep 6:30279. https://doi.org/10.1038/srep30279

43. Bublin M, Eiwegger T, Breiteneder H (2014) Do lipids influence the allergic sensitization process? J Allergy Clin Immunol 134:521-529. https://doi.org/10.1016/j.jaci.2014.04.015

44. de Jong AJ, Kloppenburg M, Toes REM, Ioan-Facsinay A (2014) Fatty acids, lipid mediators, and T-cell function. Front Immunol 5. https://doi.org/10.3389/fimmu.2014.00483

45. Tordesillas L, Gómez-Casado C, Garrido-Arandia M, MuruaGarcía A, Palacín A, Varela J, Konieczna P, Cuesta-Herranz J, Akdis CA, O'Mahony L, Díaz-Perales A (2013) Transport of Pru p 3 across gastrointestinal epithelium - an essential step towards the induction of food allergy? Clin Exp Allergy 43:1374-1383. https://doi.org/10.1111/cea.12202

46. Hauser M, Roulias A, Ferreira F, Egger M (2010) Panallergens and their impact on the allergic patient. Allergy Asthma Clin Immunol 6:1-14. https://doi.org/10.1186/1710-1492-6-1

47. Salcedo G, Sánchez-Monge R, García-Casado G, Armentia A, Gomez L, Barber D (2004) The cereal $\alpha$-amylase/trypsin inhibitor family associated with Bakers' asthma and food allergy. In: Mills ENC, Shewry PR (eds) Plant Food Allergens. Blackwell Science Ltd, Oxford, pp 70-86

48. Salcedo G, Quirce S, Diaz-Perales A (2011) Wheat allergens associated with Baker's asthma. J Investig Allergol Clin Immunol 21:81-92. http://www.jiaci.org/issues/vol21issue2/1.pdf

49. Altenbach SB, Vensel WH, Dupont FM (2011) The spectrum of low molecular weight alpha-amylase/protease inhibitor genes expressed in the US bread wheat cultivar Butte 86. BMC Res Notes 4:242. https://doi.org/10.1186/1756-0500-4-242

50. Geisslitz S, Ludwig C, Scherf KA, Koehler P (2018) Targeted LCMS/MS reveals similar contents of $\alpha$-amylase/trypsin-inhibitors as putative triggers of nonceliac gluten sensitivity in all wheat species except einkorn. J Agric Food Chem 66:12395-12403. https://doi.org/10.1021/acs.jafc.8b04411

51. Kusaba-Nakayama M, Ki M, Iwamoto M, Shibata R, Sato M, Imaizumi K (2000) CM3, one of the wheat $\alpha$-amylase inhibitor subunits, and binding of IgE in sera from Japanese with atopic dermatitis related to wheat. Food Chem Toxicol 38:179-185 https://doi.org/10.1016/S0278-6915(99)00143-X

52. Mäkelä MJ, Eriksson C, Kotaniemi-Syrjänen A, Palosuo K, Marsh J, Borres M, Kuitunen M, Pelkonen AS (2014) Wheat allergy in children - new tools for diagnostics. Clin Exp Allergy 44:14201430. https://doi.org/10.1111/cea.12393

53. James JM, Sixbey JP, Helm RM, Bannon GA, Burks AW (1997) Wheat a-amylase inhibitor: A second route of allergic sensitization. J Allergy Clin Immunol 99:239-244. https://doi.org/10.1016/S0091-6749(97)70103-9

54. Tatham AS, Shewry PR (2008) Allergens to wheat and related cereals. Clin Exp Allergy 38:1712-1726. https://doi.org/10.1111/j.1365-2222.2008.03101.x

55. Zapatero L, Martínez MI, Alonso E, Salcedo G, Sánchez-Monge R, Barber D, Lombardero M (2003) Oral wheat flour anaphylaxis related to wheat $\alpha$-amylase inhibitor subunits CM3 and CM16. Allergy 58:956-956. https://doi.org/10.1034/j.13989995.2003.00158.x

56. Wieser H (2007) Chemistry of gluten proteins. Food Microbiol 24:115-119. https://doi.org/10.1016/j.fm.2006.07.004

57. Shewry PR, Tatham AS (1990) The prolamin storage proteins of cereal seeds: structure and evolution. Biochem J 267:1-12. https://doi.org/10.1042/bj2670001

58. Barak S, Mudgil D, Khatkar BS (2015) Biochemical and functional properties of wheat gliadins: A review. Crit Rev Food Sci Nutr 55:357-368. https://doi.org/10.1080/10408398.2012.654863

59. Tatham AS, Miflin BJ, Shewry PR (1985) The beta-turn conformation in wheat gluten proteins: Relationship to gluten elasticity. Cereal Chem 62:405-412 http://www.aaccnet.org/publications/cc/backissues/1985/Docume nts/chem62 405.pdf

60. Müller S, Wieser H (1995) The location of disulphide bonds in $\alpha$ type gliadins. J Cereal Sci 22:21-27. https://doi.org/10.1016/S0733-5210(05)80004-9

61. Müller S, Wieser H (1997) The location of disulphide bonds in monomeric y-type gliadins. J Cereal Sci 26:169-176. https://doi.org/10.1006/S0733-5210(97)90100-4

62. Matsuo H, Kohno K, Morita E (2005) Molecular cloning, recombinant expression and IgE-binding epitope of $\omega-5$ gliadin, a major allergen in wheat-dependent exercise-induced anaphylaxis. FEBS J 272:4431-4438. https://doi.org/10.1111/j.1742 4658.2005.04858.x

63. Rodríguez del Río P, Díaz-Perales A, Sánchez-García S, Escudero C, Ibáñez MD, Méndez-Brea P, Barber D (2018) Profilin, a change in the paradigm. J Investig Allergol Clin Immunol 28:1-12. https://doi.org/10.18176/jiaci.0193

64. Santos A, Van Ree R (2011) Profilins: mimickers of allergy or relevant allergens? Int Arch Allergy Immunol 155:191-204. https://doi.org/10.1159/000321178

65. Asturias JA, Gómez-Bayón N, Arilla MC, Sánchez-Pulido L, Valencia A, Martínez A (2002) Molecular and structural analysis of the panallergen profilin B cell epitopes defined by monoclonal antibodies. Int Immunol 14:993-1001. https://doi.org/10.1093/intimm/dxf070

66. Krishnan K, Moens PDJ (2009) Structure and functions of profilins. Biophys Rev 1:71-81. https://doi.org/10.1007/s12551-009-0010-y

67. Radauer C, Hoffmann-Sommergruber K (2004) Profilins. In: Mills ENC, Shewry PR (eds) Plant Food Allergens. Blackwell Science, Oxford, pp 105-124

68. Limmongkon A, Giuliani C, Valenta R, Mittermann I, HeberleBors E, Wilson C (2004) MAP kinase phosphorylation of plant profilin. Biochem Biophys Res Commun 324:382-386. https://doi.org/10.1016/i.bbrc.2004.09.071 
69. Mills EN, Jenkins J, Marigheto N, Belton PS, Gunning AP, Morris VJ (2002) Allergens of the cupin superfamily. Biochem Soc Trans 30:925-929. https://doi.org/10.1042/bst0300925

70. Alessandri S, Sancho A, Vieths S, Mills CEN, Wal J-M, Shewry PR, Rigby N, Hoffmann-Sommergruber K (2012) Highthroughput NMR assessment of the tertiary structure of food allergens. Plos $\quad$ One $\quad$ 7:e39785. https://doi.org/10.1371/journal.pone.0039785

71. van Boxtel EL, van den Broek LAM, Koppelman SJ, Gruppen H (2008) Legumin allergens from peanuts and soybeans: Effects of denaturation and aggregation on allergenicity. Mol Nutr Food Res 52:674-682. https://doi.org/10.1002/mnfr.200700299

72. Uasuf CG, De Angelis E, Guagnano R, Pilolli R, D'Anna C, Villalta D, Brusca I, Monaci L (2020) Emerging allergens in Goji berry superfruit: The identification of new IgE binding proteins towards allergic patients' sera. Biomolecules 10:689. https://doi.org/10.3390/biom10050689

73. Ekramoddoullah AKM (2004) Physiology and molecular biology of a family of pathogenesis-related PR-10 proteins in conifers. J Crop Improv 10:261-280. https://doi.org/10.1300/J411v10n01 11

74. Somssich IE, Schmelzer E, Kawalleck P, Hahlbrock K (1988) Gene structure and in situ transcript localization of pathogenesis-related protein 1 in parsley. Mol Gen Genet 213:93-98. https://doi.org/10.1007/bf00333403

75. Jain S, Kumar A (2015) The pathogenesis related class 10 proteins in plant defense against biotic and abiotic stresses Adv Plants Agric Res 2:00077. https://doi.org/10.15406/apar.2015.02.00077

76. Fernandes H, Michalska K, Sikorski M, Jaskolski M (2013) Structural and functional aspects of PR-10 proteins. FEBS J 280:1169-1199. https://doi.org/10.1111/febs.12114

77. Liu J-J, Ekramoddoullah AKM (2006) The family 10 of plant pathogenesis-related proteins: Their structure, regulation, and function in response to biotic and abiotic stresses. Physiol Mol Plant Pathol 68:3-13. https://doi.org/10.1016/i.pmpp.2006.06.004

78. Sinha M, Singh RP, Kushwaha GS, Iqbal N, Singh A, Kaushik S, Kaur P, Sharma S, Singh TP (2014) Current Overview of allergens of plant Pathogenesis related protein families. Sci World J 2014:543195. https://doi.org/10.1155/2014/543195

79. David H, Hofmann G, Oliveira AP, Jarmer H, Nielsen J (2006) Metabolic network driven analysis of genome-wide transcription data from Aspergillus nidulans. Genome Biol 7:R108. https://doi.org/10.1186/gb-2006-7-11-r108

80. Hoffmann-Sommergruber K (2000) Plant allergens and pathogenesis-related proteins. What do they have in common? Int Arch Allergy Immunol 122:155-166. https://doi.org/10.1159/000024392

81. Hoffmann-Sommergruber K (2002) Pathogenesis-related (PR)proteins identified as allergens. Biochem Soc Trans 30:930-935. https://doi.org/10.1042/bst0300930

82. Midoro-Horiuti T, Brooks EG, Goldblum RM (2001) Pathogenesisrelated proteins of plants as allergens. Ann Allergy Asthma Immunol 87:261-271. https://doi.org/10.1016/S10811206(10)62238-7

83. Radauer C, Nandy A, Ferreira F, Goodman RE, Larsen JN, Lidholm J, Pomés A, Raulf-Heimsoth M, Rozynek P, Thomas WR, Breiteneder $\mathrm{H}$ (2014) Update of the WHO/IUIS Allergen Nomenclature Database based on analysis of allergen sequences. Allergy 69:413-419. https://doi.org/10.1111/all.12348

84. Renz H, Allen KJ, Sicherer SH, Sampson HA, Lack G, Beyer K, Oettgen HC (2018) Food allergy. Nat Rev Dis Primers 4:17098. https://doi.org/10.1038/nrdp.2017.98

85. Mazzucchelli G, Holzhauser T, Velickovic TC, Diaz-Perales A, Molina E, Roncada P, Rodrigues P, Verhoeckx K, HoffmannSommergruber K (2018) Current (food) allergenic risk assessment: Is it fit for novel foods? Status quo and identification of gaps. Mol Nutri Food Res 62:1700278. https://doi.org/10.1002/mnfr.201700278

86. Sun N, Zhou C, Zhou X, Sun L, Che H (2015) Use of a rat basophil leukemia (RBL) cell-based immunological assay for allergen identification, clinical diagnosis of allergy, and identification of anti-allergy agents for use in immunotherapy. J Immunotoxicol 12:199-205. https://doi.org/10.3109/1547691X.2014.920063

87. Gomes-Belo J, Hannachi F, Swan K, Santos AF (2018) Advances in food allergy diagnosis. Curr Pediatr Rev 14:139-149. https://doi.org/10.2174/1573396314666180423105842
88. Simonato B, Pasini G, Giannattasio M, Peruffo ADB, De Lazzari F, Curioni A (2001) Food allergy to wheat products: The effect of bread baking and in vitro digestion on wheat allergenic proteins. A study with bread dough, crumb, and crust. J Agric Food Chem 49:5668-5673. https://doi.org/10.1021/jf0104984

89. De Zorzi M, Curioni A, Simonato B, Giannattasio M, Pasini G (2007) Effect of pasta drying temperature on gastrointestinal digestibility and allergenicity of durum wheat proteins. Food Chem 104:353-363. https://doi.org/10.1016/j.foodchem.2006.11.057

90. Jankiewicz A, Aulepp H, Baltes W, Bögl KW, Dehne LI, Zuberbier T, Vieths S (1996) Allergic sensitization to native and heated celery root in pollen-sensitive patients investigated by skin test and IgE binding. Int Arch Allergy Immunol 111:268-278. https://doi.org/10.1159/000237377

91. Jankiewicz A, Baltes W, Bögl KW, Dehne LI, Jamin A, Hoffmann A, Haustein D, Vieths S (1997) Influence of food processing on the immunochemical stability of celery allergens. J Sci Food Agric 75:359-370. https://doi.org/10.1002/(SICI)1097 0010(199711)75:3<359::AID-JSFA889>3.0.CO;2-Y

92. Lupi R, Masci S, Rogniaux H, Tranquet O, Brossard C, Lafiandra D, Moneret-Vautrin DA, Denery-Papini S, Larré C (2014) Assessment of the allergenicity of soluble fractions from GM and commercial genotypes of wheats. J Cereal Sci 60:179-186. https://doi.org/10.1016/j.jcs.2014.02.009

93. Consolini M, Sega M, Zanetti C, Fusi M, Chignola R, De Carli M, Rizzi C, Zoccatelli G (2012) Emulsification of simulated gastric fluids protects wheat $\alpha$-amylase inhibitor 0.19 epitopes from digestion. Food Anal Meth 5:234-243. https://doi.org/10.1007/s12161-011-9227-z

94. Asero R, Mistrello G, Roncarolo D, Amato S, Zanoni D, Barocci F, Caldironi G (2003) Detection of clinical markers of sensitization to profilin in patients allergic to plant-derived foods. J Allergy Clin Immunol 112:427-432. https://doi.org/10.1067/mai.2003.1611

95. Primavesi L, Pravettoni V, Brenna O, Farioli L, Pastorello E, Pompei C (2011) Influence of technological processing on the allergenicity of tomato products. Eur Food Res Technol 232:631 636. https://doi.org/10.1007/s00217-011-1428-6

96. Cuadrado C, Cheng H, Sanchiz A, Ballesteros I, Easson M, Grimm CC, Dieguez MC, Linacero R, Burbano C, Maleki SJ (2018) Influence of enzymatic hydrolysis on the allergenic reactivity of processed cashew and pistachio. Food Chem 241:372-379. https://doi.org/10.1016/j.foodchem.2017.08.120

97. Mattison CP, Desormeaux WA, Wasserman RL, Yoshioka-Tarver M, Condon B, Grimm CC (2014) Decreased immunoglobulin E (IgE) binding to cashew allergens following sodium sulfite treatment and heating. J Agric Food Chem 62:6746-6755. https://doi.org/10.1021/jf501117p

98. Cabanillas B, Pedrosa MM, Rodríguez J, Muzquiz M, Maleki SJ, Cuadrado C, Burbano C, Crespo JF (2012) Influence of enzymatic hydrolysis on the allergenicity of roasted peanut protein extract. Int Arch Allergy Immunol 157:41-50. https://doi.org/10.1159/000324681

99. Mattison CP, Dinter J, Berberich MJ, Chung S-Y, Reed SS, Le Gall S, Grimm CC (2015) In vitro evaluation of digestive and endolysosomal enzymes to cleave CML-modified Ara h 1 $\begin{array}{llll}\text { peptides. } & \text { Food } & \text { Sci } & \text { Nutr }\end{array}$ https://doi.org/10.1002/fsn3.215

100. Blanc F, Vissers YM, Adel-Patient K, Rigby NM, Mackie AR, Gunning AP, Wellner NK, Skov PS, Przybylski-Nicaise L, Ballmer-Weber B, Zuidmeer-Jongejan L, Szépfalusi Z, Ruinemans-Koerts J, Jansen APH, Bernard H, Wal JM, Savelkoul HFJ, Wichers HJ, Mills ENC (2011) Boiling peanut Ara h 1 results in the formation of aggregates with reduced allergenicity. Mol Nutr Food Res 55:1887-1894. https://doi.org/10.1002/mnfr.201100251

101. Maleki SJ, Kopper RA, Shin DS, Park C-W, Compadre CM, Sampson H, Burks AW, Bannon GA (2000) Structure of the major peanut allergen Ara h 1 may protect ige-binding epitopes from degradation. $\quad J \quad$ Immunol https://doi.org/10.4049/jimmunol.164.11.5844

102. Radosavljevic J, Nordlund E, Mihajlovic L, Krstic M, Bohn T, Buchert J, Velickovic TC, Smit J (2014) Sensitizing potential of enzymatically cross-linked peanut proteins in a mouse model of peanut allergy. Mol Nutr Food Res 58:635-646. https://doi.org/10.1002/mnfr.201300403 
103. Vissers YM, Blanc F, Skov PS, Johnson PE, Rigby NM, Przybylski-Nicaise L, Bernard H, Wal J-M, Ballmer-Weber B, Zuidmeer-Jongejan L, Szépfalusi Z, Ruinemans-Koerts J, Jansen APH, Savelkoul HFJ, Wichers HJ, Mackie AR, Mills CEN, AdelPatient K (2011) Effect of heating and glycation on the allergenicity of $2 \mathrm{~S}$ albumins (Ara h $2 / 6$ ) from peanut. PLOS ONE 6:e23998. https://doi.org/10.1371/journal.pone.0023998

104. Cabanillas B, Maleki SJ, Rodríguez J, Cheng H, Teuber SS, Wallowitz ML, Muzquiz M, Pedrosa MM, Linacero R, Burbano C, Novak N, Cuadrado C, Crespo JF (2014) Allergenic properties and differential response of walnut subjected to processing treatments. Food Chem 157:141-147. https://doi.org/10.1016/j.foodchem.2014.02.025

105. Angelina A, Sirvent S, Palladino C, Vereda A, Cuesta-Herranz J, Eiwegger T, Rodríguez R, Breiteneder H, Villalba M, Palomares O (2016) The lipid interaction capacity of Sin a 2 and Ara h 1, major mustard and peanut allergens of the cupin superfamily, endorses allergenicity. Allergy 71:1284-1294. https://doi.org/10.1111/all.12887

106. Schimek EM, Zwölfer B, Briza P, Jahn-Schmid B, Vogel L, Vieths S, Ebner C, Bohle B (2005) Gastrointestinal digestion of Bet v 1homologous food allergens destroys their mediator-releasing, but not T cell-activating capacity. J Allergy Clin Immunol 116:13271333. https://doi.org/10.1016/j.jaci.2005.09.007

107. Bohle B, Zwölfer B, Heratizadeh A, Jahn-Schmid B, Antonia YD, Alter M, Keller W, Zuidmeer L, van Ree R, Werfel T, Ebner C (2006) Cooking birch pollen-related food: divergent consequences for IgE- and $\mathrm{T}$ cell-mediated reactivity in vitro and in vivo. $\mathrm{J}$ Allergy Clin Immunol 118:242-249. https://doi.org/10.1016/j.jaci.2006.03.011

108. Goliáš J, Humlová Z, Halada P, Hábová V, Janatková I, Tučková $\mathrm{L}$ (2013) Identification of rice proteins recognized by the $\operatorname{IgE}$ antibodies of patients with food allergies. J Agric Food Chem 61:8851-8860. https://doi.org/10.1021/jf402759f

109. Zevallos VF, Raker V, Tenzer S, Jimenez-Calvente C, AshfaqKhan M, Rüssel N, Pickert G, Schild H, Steinbrink K, Schuppan D (2017) Nutritional wheat amylase-trypsin inhibitors promote intestinal inflammation via activation of myeloid cells. Gastroenterology https://doi.org/10.1053/j.gastro.2016.12.006

110. Vassilopoulou E, Rigby N, Moreno FJ, Zuidmeer L, Akkerdaas J, Tassios I, Papadopoulos NG, Saxoni-Papageorgiou P, van Ree R, Mills C (2006) Effect of in vitro gastric and duodenal digestion on the allergenicity of grape lipid transfer protein. J Allergy Clin Immunol 118:473-480. https://doi.org/10.1016/j.jaci.2006.04.057

111. Hiragun $M$, Ishii $K$, Hiragun $T$, Shindo $H$, Mihara $S$, Matsuo $H$, Hide M (2013) The sensitivity and clinical course of patients with wheat-dependent exercise-induced anaphylaxis sensitized to hydrolyzed wheat protein in facial soap - secondary publication. Allergol Int 62:351-358. https://doi.org/10.2332/allergolint.13OA-0553

112. Lupi R, Denery-Papini S, Claude M, Tranquet O, Drouet M, Masci $S$, Larré C (2019) Thermal treatment reduces gliadin recognition by $\operatorname{IgE}$, but a subsequent digestion and epithelial crossing permits recovery. Food Res Int 118:22-31. https://doi.org/10.1016/j.foodres.2018.02.011

113. Bernard H, Guillon B, Drumare M-F, Paty E, Dreskin SC, Wal JM, Adel-Patient K, Hazebrouck S (2015) Allergenicity of peanut component Ara h 2: Contribution of conformational versus linear hydroxyproline-containing epitopes. J Allergy Clin Immunol 135:1267-1274.e1268. https://doi.org/10.1016/j.jaci.2014.10.025

114. Cabanillas B, Crespo JF, Maleki SJ, Rodriguez J, Novak N (2016) Pin $\mathrm{p} 1$ is a major allergen in pine nut and the first food allergen described in the plant group of gymnosperms. Food Chem 210:7077. https://doi.org/10.1016/j.foodchem.2016.04.068

115. Tscheppe A, Palmberger D, van Rijt L, Kalic T, Mayr V, Palladino C, Kitzmüller C, Hemmer W, Hafner C, Bublin M, van Ree R, Grabherr R, Radauer C, Breiteneder H (2020) Development of a novel Ara $\mathrm{h} 2$ hypoallergen with no $\operatorname{IgE}$ binding or anaphylactogenic activity. J Allergy Clin Immunol 145:229-238. https://doi.org/10.1016/j.jaci.2019.08.036

116. Vissers YM, Iwan M, Adel-Patient K, Skov PS, Rigby NM, Johnson PE, Müller PM, Przybylski-Nicaise L, Schaap M, Ruinemans-Koerts J, Jansen APH, Mills ENC, Savelkoul HFJ, Wichers HJ (2011) Effect of roasting on the allergenicity of major peanut allergens Ara $h 1$ and Ara $h$ 2/6: the necessity of degranulation assays. Clin Exp Allergy 41:1631-1642. https://doi.org/10.1111/j.1365-2222.2011.03830.x

117. Cabanillas B, Cuadrado C, Rodriguez J, Hart J, Burbano C, Crespo JF, Novak N (2015) Potential changes in the allergenicity of three forms of peanut after thermal processing. Food Chem 183:18-25. https://doi.org/10.1016/j.foodchem.2015.03.023

118. Scheurer S, Lauer I, Foetisch K, Moncin MSM, Retzek M, Hartz C, Enrique E, Lidholm J, Cistero-Bahima A, Vieths S (2004) Strong allergenicity of Pru av 3, the lipid transfer protein from cherry, is related to high stability against thermal processing and digestion. J Allergy Clin Immunol 114:900-907. https://doi.org/10.1016/j.jaci.2004.06.017

119. Sancho AI, Rigby NM, Zuidmeer L, Asero R, Mistrello G, Amato S, González-Mancebo E, Fernández-Rivas M, van Ree R, Mills ENC (2005) The effect of thermal processing on the IgE reactivity of the non-specific lipid transfer protein from apple, Mal d 3 . Allergy 60:1262-1268. https://doi.org/10.1111/j.13989995.2005.00876.X

120. Sancho AI, van Ree R, van Leeuwen A, Meulenbroek BJ, van de Weg EW, Gilissen LJWJ, Puehringer H, Laimer M, Martinelli A, Zaccharini M, Vazquez-Cortés S, Fernandez-Rivas M, HoffmannSommergruber K, Mills ENC, Zuidmeer L (2008) Measurement of lipid transfer protein in 88 apple cultivars. Int Arch Allergy Immunol 146:19-26. https://doi.org/10.1159/000112499

121. Denery-Papini S, Bodinier M, Larré C, Brossard C, Pineau F, Triballeau S, Pietri M, Battais F, Mothes T, Paty E, MoneretVautrin DA (2012) Allergy to deamidated gluten in patients tolerant to wheat: specific epitopes linked to deamidation. Allergy 67:1023-1032. https://doi.org/10.1111/j.1398-9995.2012.02860.x

122. Mameri H, Brossard C, Gaudin J-C, Gohon Y, Paty E, Beaudouin E, Moneret-Vautrin D-A, Drouet M, Solé V, Wien F, Lupi R, Larré C, Snégaroff J, Denery-Papini S (2015) Structural basis of IgE binding to $\alpha$ - and $\gamma$-gliadins: Contribution of disulfide bonds and repetitive and nonrepetitive domains. J Agric Food Chem 63:65466554. https://doi.org/10.1021/acs.jafc.5b01922

123. Gourbeyre P, Denery-Papini S, Larré C, Gaudin JC, Brossard C, Bodinier M (2012) Wheat gliadins modified by deamidation are more efficient than native gliadins in inducing a Th2 response in $\mathrm{Balb} / \mathrm{c}$ mice experimentally sensitized to wheat allergens. Mol Nutr Food Res 56:336-344. https://doi.org/10.1002/mnfr.201100353

124. Hansen KS, Ballmer-Weber BK, Lüttkopf D, Skov PS, Wüthrich B, Bindslev-Jensen C, Vieths S, Poulsen LK (2003) Roasted hazelnuts - allergenic activity evaluated by double-blind, placebocontrolled food challenge. Allergy 58:132-138. https://doi.org/10.1034/j.1398-9995.2003.23959.x

125. Eiwegger T, Rigby N, Mondoulet L, Bernard H, Krauth MT, Boehm A, Dehlink E, Valent P, Wal JM, Mills ENC, Szépfalusi Z (2006) Gastro-duodenal digestion products of the major peanut allergen Ara h 1 retain an allergenic potential. Clin Exp Allergy 36:1281-1288. https://doi.org/10.1111/j.1365-2222.2006.02565.x

126. Murtagh GJ, Archer DB, Dumoulin M, Ridout S, Matthews S, Arshad SH, Alcocer MJC (2003) In vitro stability and immunoreactivity of the native and recombinant plant food $2 \mathrm{~S}$ albumins Ber e 1 and SFA-8. Clin Exp Allergy 33:1147-1152. https://doi.org/10.1046/j.1365-2222.2003.01736.x

127. Houska M, Heroldova M, Vavrova H, Kucera P, Setinova I Havranova M, Honzova S, Strohalm J, Kminkova M, Proskova A, Novotna P (2009) Is high-pressure treatment able to modify the allergenicity of the main apple juice allergen, Mal d1? High Pressure Res 29:14-22 https://doi.org/10.1080/08957950802454068

128. Setinova I, Trnkova B, Honzova S, Kvacova A, Heroldova M Vavrova H, Kucera P, Kminkova M, Strohalm J, Pruchova J, Novotna P, Houska M (2009) The influence of oxidative and polymerisation processes of apple juice on allergenicity of protein Mal d 1 in apple juice. Allergy 64:244-244. https://doi.org/10.1111/j.1398-9995.2009.02076.x

129. Ballmer-Weber BK, Hoffmann A, Wüthrich B, Lüttkopf D, Pompei C, Wangorsch A, Kästner M, Vieths S (2002) Influence of food processing on the allergenicity of celery: DBPCFC with celery spice and cooked celery in patients with celery allergy. Allergy 57:228-235. https://doi.org/10.1034/j.1398 9995.2002.103319.x 
130. Adachi A, Horikawa T, Shimizu H, Sarayama Y, Ogawa T, Sjolander S, Tanaka A, Moriyama T (2009) Soybean $\beta$ conglycinin as the main allergen in a patient with food-dependent exercise-induced anaphylaxis by tofu: food processing alters pepsin resistance. Clin Exp Allergy 39:167-173. https://doi.org/10.1111/j.1365-2222.2008.03148.x

131. Nakamura M, Yagami A, Hara K, Sano-Nagai A, Kobayashi T, Matsunaga K (2016) Evaluation of the cross-reactivity of antigens in Glupearl 19S and other hydrolysed wheat proteins in cosmetics. Contact Dermatitis 74:346-352. https://doi.org/10.1111/cod.12551

132. Palosuo K, Varjonen E, Nurkkala J, Kalkkinen N, Harvima R, Reunala T, Alenius H (2003) Transglutaminase-mediated crosslinking of a peptic fraction of $\omega-5$ gliadin enhances $\mathrm{IgE}$ reactivity in wheat-dependent, exercise-induced anaphylaxis. J Allergy Clin Immunol 111:1386-1392. https://doi.org/10.1067/mai.2003.1498

133. Sato S, Yanagida N, Ohtani K, Koike Y, Ebisawa M (2015) A review of biomarkers for predicting clinical reactivity to foods with a focus on specific immunoglobulin $\mathrm{E}$ antibodies. Curr Opin Allergy Clin Immunol 15:250-258. https://doi.org/10.1097/aci.0000000000000162

134. Starkl P, Krishnamurthy D, Szalai K, Felix F, Lukschal A, Oberthuer D, Sampson HA, Swoboda I, Betzel C, Untersmayr E, Jensen-Jarolim E (2011) Heating affects structure, enterocyte adsorption and signalling, as well as immunogenicity of the peanut allergen Ara h 2. Open Allergy J 4:24-34. https://doi.org/10.2174/1874838401104010024

135. Mirotti L, Florsheim E, Rundqvist L, Larsson G, Spinozzi F, Leitede-Moraes M, Russo M, Alcocer M (2013) Lipids are required for the development of Brazil nut allergy: the role of mouse and human iNKT cells. Allergy 68:74-83. https://doi.org/10.1111/all.12057

136. Kumagai H, Suda A, Sakurai H, Kumagai H, Arai S, Inomata N, Ikezawa Z (2007) Improvement of digestibility, reduction in allergenicity, and induction of oral tolerance of wheat gliadin by deamidation. Biosci Biotechnol Biochem 71:977-985. https://doi.org/10.1271/bbb.60645

137. Bouferkas Y, Haddi A, Mehedi N, Saidi D, Kheroua O (2019) Enzymatic treatment of gliadins triggers anaphylactic reaction in a murine model of wheat allergy: in vivo and ex vivo study. Biosci Res 16:1377-1390. https://www.isisn.org/BR16(2)2019/13771390-16(2)2019BR19-132.pdf

138. Zhang W, Zhu Q, Zhang T, Cai Q, Chen Q (2016) Thermal processing effects on peanut allergen Ara $\mathrm{h} 2$ allergenicity in mice and its antigenic epitope structure. Food Chem 212:657-662. https://doi.org/10.1016/j.foodchem.2016.06.036

139. McClain S, Bowman C, Fernández-Rivas M, Ladics GS, Ree Rv (2014) Allergic sensitization: food- and protein-related factors. Clin Transl Allergy 4:11. https://doi.org/10.1186/2045-7022-4-11

140. Smits M, Le T-M, Welsing P, Houben G, Knulst A, Verhoeckx K (2018) Legume protein consumption and the prevalence of legume sensitization. Nutrients 10:1545. https://doi.org/10.3390/nu10101545

141. Ogo Y, Wakasa Y, Hirano K, Urisu A, Matsuda T, Takaiwa F (2014) Generation of transgenic rice with reduced content of major and novel high molecular weight allergens. Rice 7:19-19. https://doi.org/10.1186/s12284-014-0019-0

142. Wakasa Y, Hirano K, Urisu A, Matsuda T, Takaiwa F (2011) Generation of transgenic rice lines with reduced contents of multiple potential allergens using a null mutant in combination with an RNA silencing method. Plant Cell Physiol 52:2190-2199. https://doi.org/10.1093/pcp/pcr151

143. Dubois AEJ, Pagliarani G, Brouwer RM, Kollen BJ, Dragsted LO, Eriksen FD, Callesen O, Gilissen LJWJ, Krens FA, Visser RGF, Smulders MJM, Vlieg-Boerstra BJ, Flokstra-de Blok BJ, van de Weg WE (2015) First successful reduction of clinical allergenicity of food by genetic modification: Mal d 1-silenced apples cause fewer allergy symptoms than the wild-type cultivar. Allergy 70:1406-1412. https://doi.org/10.1111/all.12684

144. Monsalve RI, Villalba M, Rico M, Shewry PR, Rodríguez R (2004) The 2S Albumin Proteins. In: Mills ENC, Shewry PR (eds) Plant Food Allergens. Blackwell Publishing Company, Oxford, UK, pp 42-56

145. Radauer C, Willerroider M, Fuchs H, Hoffmann-Sommergruber K, Thalhamer J, Ferreira F, Scheiner O, Breiteneder H (2006) Cross-reactive and species-specific immunoglobulin E epitopes of plant profilins: an experimental and structure-based analysis. Clin
Exp Allergy 36:920-929. https://doi.org/10.1111/j.1365 2222.2006.02521.x

146. Ladics GS, Bartholomaeus A, Bregitzer P, Doerrer NG, Gray A Holzhauser T, Jordan M, Keese P, Kok E, Macdonald P, Parrott W, Privalle L, Raybould A, Rhee SY, Rice E, Romeis J, Vaughn J, Wal J-M, Glenn K (2015) Genetic basis and detection of unintended effects in genetically modified crop plants. Transgenic Res 24:587-603. https://doi.org/10.1007/s11248-015-9867-7

147. Ladics GS, Fry J, Goodman R, Herouet-Guicheney C, HoffmannSommergruber K, Madsen CB, Penninks A, Pomés A, Roggen EL, Smit J, Wal J-M (2014) Allergic sensitization: screening methods. Clin Transl Allergy 4:13-13. https://doi.org/10.1186/2045-7022-413

148. Dall'Antonia F, Pavkov-Keller T, Zangger K, Keller W (2014) Structure of allergens and structure based epitope predictions. Methods 66:3-21. https://doi.org/10.1016/j.ymeth.2013.07.024

149. Sirvent S, Palomares O, Cuesta-Herranz J, Villalba M, Rodríguez R (2012) Analysis of the structural and immunological stability of $2 \mathrm{~S}$ albumin, nonspecific lipid transfer protein, and profilin allergens from mustard seeds. J Agric Food Chem 60:6011-6018. https://doi.org/10.1021/jf300555h

150. Gaier S, Marsh J, Oberhuber C, Rigby NM, Lovegrove A, Alessandri S, Briza P, Radauer C, Zuidmeer L, van Ree R, Hemmer W, Sancho AI, Mills C, Hoffmann-Sommergruber K, Shewry PR (2008) Purification and structural stability of the peach allergens Pru p 1 and Pru p 3. Mol Nutr Food Res 52:S220-S229. https://doi.org/10.1002/mnfr.200700274

151. Bu G, Zhu T, Chen F (2017) The structural properties and antigenicity of soybean glycinin by glycation with xylose. J Sci Food Agric 97:2256-2262. https://doi.org/10.1002/jsfa.8036

152. Lehmann K, Schweimer K, Reese G, Randow S, Suhr M, Becker W-M, Vieths S, Rösch P (2006) Structure and stability of 2 S albumin-type peanut allergens: implications for the severity of peanut allergic reactions. Biochem J 395:463-472. https://doi.org/10.1042/BJ20051728

153. Apostolovic D, Luykx D, Warmenhoven H, Verbart D, StanicVucinic D, de Jong GAH, Velickovic TC, Koppelman SJ (2013) Reduction and alkylation of peanut allergen isoforms Ara h 2 and Ara h 6; characterization of intermediate- and end products. BBAProteins Proteomics 1834:2832-2842. https://doi.org/10.1016/j.bbapap.2013.10.004

154. Audagnotto M, Dal Peraro M (2017) Protein post-translationa modifications: In silico prediction tools and molecular modeling. $\begin{array}{llll}\text { Comp Struct } & \text { Biotechnol J }\end{array}$ https://doi.org/10.1016/j.csbj.2017.03.004

155. Wolfert MA, Boons G-J (2013) Adaptive immune activation: glycosylation does matter. Nat Chem Biol 9:776. https://doi.org/10.1038/nchembio.1403

156. Knorre DG, Kudryashova NV, Godovikova TS (2009) Chemical and functional aspects of posttranslational modification of proteins. Acta Naturae 1:29-51. http://www.ncbi.nlm.nih.gov/pmc/articles/PMC3347534/

157. Shreffler WG, Castro RR, Kucuk ZY, Charlop-Powers Z, Grishina G, Yoo S, Burks AW, Sampson HA (2006) The major glycoprotein allergen from Arachis hypogaea, Ara h 1, is a ligand of dendritic cell-specific ICAM-grabbing nonintegrin and acts as a Th2 adjuvant in vitro. J Immunol 177:3677-3685. https://doi.org/10.4049/jimmunol.177.6.3677

158. Lauer I, Foetisch K, Kolarich D, Ballmer-Weber BK, Conti A Altmann F, Vieths S, Scheurer S (2004) Hazelnut (Corylus avellana) vicilin Cor a 11: molecular characterization of a glycoprotein and its allergenic activity. Biochem J 383:327-334. https://doi.org/10.1042/bj20041062

159. Liu J, Ru Q, Ding Y (2012) Glycation a promising method for food protein modification: Physicochemical properties and structure, a review. Food Res Int 49:170-183. https://doi.org/10.1016/j.foodres.2012.07.034

160. Teodorowicz M, van Neerven J, Savelkoul H (2017) Food processing: The influence of the maillard reaction on immunogenicity and allergenicity of food proteins. Nutrients 9:835. https://doi.org/10.3390/nu9080835

161. Toda M, Hellwig M, Henle T, Vieths S (2019) Influence of the Maillard reaction on the allergenicity of food proteins and the development of allergic inflammation. Curr Allergy Asthma Rep 19:4. https://doi.org/10.1007/s11882-019-0834-x 
162. Gruber P, Becker W-M, Hofmann T (2005) Influence of the Maillard reaction on the allergenicity of rAra $\mathrm{h} 2$, a recombinant major allergen from peanut (Arachis hypogaea), its major epitopes, and peanut agglutinin. J Agric Food Chem 53:2289-2296. https://doi.org/10.1021/jf048398w

163. Guillon B, Bernard H, Drumare MF, Hazebrouck S, Adel-Patient $\mathrm{K}$ (2016) Heat processing of peanut seed enhances the sensitization potential of the major peanut allergen Ara h 6. Mol Nutr Food Res 60:2722-2735. https://doi.org/10.1002/mnfr.201500923

164. Iwan M, Vissers YM, Fiedorowicz E, Kostyra H, Kostyra E, Savelkoul HFJ, Wichers HJ (2011) Impact of Maillard reaction on immunoreactivity and allergenicity of the hazelnut allergen Cor a 11. J Agric Food Chem 59:7163-7171. https://doi.org/10.1021/jf2007375

165. Yang Z-H, Li C, Li Y-Y, Wang Z-H (2013) Effects of Maillard reaction on allergenicity of buckwheat allergen Fag t 3 during thermal processing. J Sci Food Agric 93:1510-1515. https://doi.org/10.1002/jsfa.5928

166. van de Lagemaat J, Manuel Silván J, Javier Moreno F, Olano A, Dolores del Castillo M (2007) In vitro glycation and antigenicity of soy proteins. Food Res Int 40:153-160. https://doi.org/10.1016/j.foodres.2006.09.006

167. Su M, Liu C, Roux KH, Gradziel TM, Sathe SK (2017) Effects of processing and storage on almond (Prunus dulcis L.) amandin immunoreactivity. Food Res Int 100:87-95. https://doi.org/10.1016/j.foodres.2017.06.061

168. Gruber P, Vieths S, Wangorsch A, Nerkamp J, Hofmann T (2004) Maillard reaction and enzymatic browning affect the allergenicity of Pru av 1, the major allergen from cherry (Prunus avium). J Agric Food Chem 52:4002-4007. https://doi.org/10.1021/jf035458+

169. Petersen A, Rennert S, Kull S, Becker W-M, Notbohm H, Goldmann T, Jappe U (2014) Roasting and lipid binding provide allergenic and proteolytic stability to the peanut allergen Ara h 8 . Biol Chem 395:239. https://doi.org/10.1515/hsz-2013-0206

170. Sander I, Rihs H-P, Doekes G, Quirce S, Krop E, Rozynek P, van Kampen V, Merget R, Meurer U, Brüning T, Raulf M (2015) Component-resolved diagnosis of baker's allergy based on specific IgE to recombinant wheat flour proteins. J Allergy Clin Immunol 135:1529-1537. https://doi.org/10.1016/j.jaci.2014.11.021

171. Amano M, Ogawa H, Kojima K, Kamidaira T, Suetsugu S, Yoshihama M, Satoh T, Samejima T, Matsumoto I (1998) Identification of the major allergens in wheat flour responsible for baker's asthma. Biochem J 330:1229-1234. https://doi.org/10.1042/bj3301229

172. Bellinghausen I, Weigmann B, Zevallos V, Reissig S, Waisman A, Schuppan D, Saloga J (2015) Exacerbation of allergen-induced gut inflammation in humanized mice by nutritional wheat alphaamylase/trypsin inhibitors. Exp Dermatol 25:E1. https://doi.org/10.1111/exd.12952

173. Pastorello EA, Vieths S, Pravettoni V, Farioli L, Trambaioli C, Fortunato D, Lüttkopf D, Calamari M, Ansaloni R, Scibilia J, Ballmer-Weber BK, Poulsen LK, Wütrich B, Hansen KS, Robino AM, Ortolani C, Conti A (2002) Identification of hazelnut major allergens in sensitive patients with positive double-blind, placebocontrolled food challenge results. J Allergy Clin Immunol 109:563-570. https://doi.org/10.1067/mai.2002.121946

174. Müller U, Lüttkopf D, Hoffmann A, Petersen A, Becker WM, Schocker F, Niggemann B, Altmann F, Kolarich D, Haustein D, Vieths S (2000) Allergens in raw and roasted hazelnuts (Corylus avellana) and their cross-reactivity to pollen. Eur Food Res Technol 212:2-12. https://doi.org/10.1007/s002170000245

175. Kiyota K, Yoshimitsu M, Satsuki-Murakami T, Akutsu K, Kajimura K, Yamano T (2017) Detection of the tomato allergen Sola 11 and evaluation of its reactivity after heat and papain treatment. Food Agric Immunol 28:1450-1459. https://doi.org/10.1080/09540105.2017.1347914

176. Mamone G, Nitride C, Picariello G, Addeo F, Ferranti P, Mackie A (2015) Tracking the fate of pasta ( $T$. durum semolina) immunogenic proteins by in vitro simulated digestion. J Agric Food Chem 63:2660-2667. https://doi.org/10.1021/jf505461x

177. Asero R, Mistrello G, Roncarolo D, Amato S, Falagiani P (2003) Analysis of the heat stability of lipid transfer protein from apple. J Allergy Clin Immunol 112:1009-1011. https://doi.org/10.1016/S0091-6749(03)02006-2
178. Maleki SJ, Chung S-Y, Champagne ET, Raufman J-P (2000) The effects of roasting on the allergenic properties of peanut proteins. J Allergy Clin Immunol 106:763-768 https://doi.org/10.1067/mai.2000.109620

179. Venkatachalam M, Monaghan EK, Kshirsagar HH, Robotham JM, O’Donnell SE, Gerber MS, Roux KH, Sathe SK (2008) Effects of processing on immunoreactivity of cashew nut (Anacardium occidentale L.) seed flour proteins. J Agric Food Chem 56:89989005. https://doi.org/10.1021/jf801199q

180. Bavaro SL, Di Stasio L, Mamone G, De Angelis E, Nocerino R, Canani RB, Logrieco AF, Montemurro N, Monaci L (2018) Effect of thermal/pressure processing and simulated human digestion on the immunoreactivity of extractable peanut allergens. Food Res Int 109:126-137. https://doi.org/10.1016/j.foodres.2018.04.021

181. Pottier L, Villamonte G, de Lamballerie M (2017) Applications of high pressure for healthier foods. Curr Opin Food Sci 16:21-27. https://doi.org/10.1016/j.cofs.2017.06.009

182. Vanga SK, Singh A, Raghavan V (2017) Review of conventional and novel food processing methods on food allergens. Crit Rev Food Sci Nutri https://doi.org/10.1080/10408398.2015.1045965

183. Rahaman T, Vasiljevic T, Ramchandran L (2016) Effect of processing on conformational changes of food proteins related to allergenicity. Trends Food Sci Technol 49:24-34. https://doi.org/10.1016/j.tifs.2016.01.001

184. Johnson PE, Van der Plancken I, Balasa A, Husband FA, Grauwet T, Hendrickx M, Knorr D, Mills ENC, Mackie AR (2010) High pressure, thermal and pulsed electric-field-induced structural changes in selected food allergens. Mol Nutr Food Res 54:1701 1710. https://doi.org/10.1002/mnfr.201000006

185. Husband FA, Aldick T, Van der Plancken I, Grauwet T, Hendrickx M, Skypala I, Mackie AR (2011) High-pressure treatment reduces the immunoreactivity of the major allergens in apple and celeriac. Mol Nutr Food Res 55:1087-1095 https://doi.org/10.1002/mnfr.201000566

186. Hu Cq, Chen Hb, Gao Jy, Luo Cp, Xiao-juan M, Tong P (2011) High-pressure microfluidisation-induced changes in the antigenicity and conformation of allergen Ara h 2 purified from Chinese peanut. J Sci Food Agric 91:1304-1309. https://doi.org/10.1002/jsfa.4318

187. Achouri A, Boye JI (2013) Thermal processing, salt and high pressure treatment effects on molecular structure and antigenicity of sesame protein isolate. Food Res Int 53:240-251. https://doi.org/10.1016/j.foodres.2013.04.016

188. Garino C, Zitelli F, Travaglia F, Col̈sson JD, Cravotto G, Arlorio $M$ (2012) Evaluation of the impact of sequential microwave/ultrasound processing on the IgE binding properties of Pru p 3 in treated peach juice. J Agric Food Chem 60:8755-8762. https://doi.org/10.1021/jf302027e

189. Ekezie F-GC, Cheng J-H, Sun D-W (2018) Effects of nonthermal food processing technologies on food allergens: A review of recent research advances. Trend Food Sci Technol 74:12-25. https://doi.org/10.1016/i.tifs.2018.01.007

190. Barbosa-Cánovas GV, Altunakar B (2006) Pulsed electric fields processing of foods: An overview. In: Raso J, Heinz V (eds) Pulsed Electric Fields Technology for the Food Industry: Fundamentals and Applications. Springer US, Boston, MA, pp 3-26. https://doi.org/10.1007/978-0-387-31122-7 1

191. Yang WW, Chung S-Y, Ajayi O, Krishnamurthy K, Konan K, Goodrich-Schneider R (2010) Use of pulsed ultraviolet light to reduce the allergenic potency of soybean extracts. Int J Food Eng 6:11. https://doi.org/10.2202/1556-3758.1876

192. Yang WW, Mwakatage NR, Goodrich-Schneider R, Krishnamurthy K, Rababah TM (2012) Mitigation of major peanut allergens by pulsed ultraviolet light. Food Bioprocess Technol 5:2728-2738. https://doi.org/10.1007/s11947-011-0615-6

193. Chung SY, Yang W, Krishnamurthy K (2008) Effects of pulsed UV-light on peanut allergens in extracts and liquid peanut butter. J Food Sci 73:C400-C404. https://doi.org/10.1111/j.17503841.2008.00784.x

194. Zoumpoulakis P, Sinanoglou VJ, Batrinou A, Strati IF, MiniadisMeimaroglou S, Sflomos K (2012) A combined methodology to detect $\gamma$-irradiated white sesame seeds and evaluate the effects on fat content, physicochemical properties and protein allergenicity. 
Food

Chem

$131: 713-721$.

https://doi.org/10.1016/j.foodchem.2011.09.049

195. Leszczynska J, Łacka A, Szemraj J, Lukamowicz J, Zegota H (2003) The effect of microwave treatment on the immunoreactivity of gliadin and wheat flour. Eur Food Res Technol 217:387-391. https://doi.org/10.1007/s00217-003-0765-5

196. Venkatachalam M, Teuber SS, Roux KH, Sathe SK (2002) Effects of roasting, blanching, autoclaving, and microwave heating on antigenicity of almond (Prunus dulcis L.) proteins. J Agric Food Chem 50:3544-3548. https://doi.org/10.1021/jf020012z

197. Mills EC, Mackie AR (2008) The impact of processing on allergenicity of food. Curr Opin Allergy Clin Immunol 8:249-253. https://doi.org/10.1097/ACI.0b013e3282ffb123

198. Terefe NS, Augustin MA (2019) Fermentation for tailoring the technological and health related functionality of food products. Crit Rev Food Sci Nutr:1-27. https://doi.org/10.1080/10408398.2019.1666250

199. Tavano OL (2013) Protein hydrolysis using proteases: An important tool for food biotechnology. J Mol Catal B Enzym 90:111. https://doi.org/10.1016/j.molcatb.2013.01.011

200. Tranquet O, Larré C, Denery-Papini S (2020) Allergic reactions to hydrolysed wheat proteins: clinical aspects and molecular structures of the allergens involved. Crit Rev Food Sci Nutr 60:147-156. https://doi.org/10.1080/10408398.2018.1516622

201. Yamada C, Izumi H, Hirano J, Mizukuchi A, Kise M, Matsuda T, Kato Y (2005) Degradation of soluble proteins including some allergens in brown rice grains by endogenous proteolytic activity during germination and heat-processing. Biosci Biotechnol Biochem 69:1877-1883. https://doi.org/10.1271/bbb.69.1877

202. Castan L, Villemin C, Claude M, Aubert P, Durand T, Neunlist M, Brossard C, Magnan A, Bodinier M, Bouchaud G (2018) Acidhydrolyzed gliadins worsen food allergies through early sensitization. Mol Nutr Food Res 62:1800159. https://doi.org/10.1002/mnfr.201800159

203. Kobayashi T, Ito T, Kawakami H, Fuzishiro K, Hirano H, Okubo Y, Tsuboi R (2015) Eighteen cases of wheat allergy and wheatdependent exercise-induced urticaria/anaphylaxis sensitized by hydrolyzed wheat protein in soap. Int J Dermatol 54:e302-e305. https://doi.org/10.1111/ijd.12767

204. Song YS, Frias J, Martinez-Villaluenga C, Vidal-Valdeverde C, de Mejia EG (2008) Immunoreactivity reduction of soybean meal by fermentation, effect on amino acid composition and antigenicity of commercial soy products. Food Chem 108:571-581. https://doi.org/10.1016/j.foodchem.2007.11.013

205. Akkerdaas J, Totis M, Barnett B, Bell E, Davis T, Edrington T, Glenn K, Graser G, Herman R, Knulst A, Ladics G, McClain S, Poulsen LK, Ranjan R, Rascle J-B, Serrano H, Speijer D, Wang R, Pereira Mouriès L, Capt A, van Ree R (2018) Protease resistance of food proteins: a mixed picture for predicting allergenicity but a useful tool for assessing exposure. Clin Transl Allergy 8:30. https://doi.org/10.1186/s13601-018-0216-9

206. Verhoeckx K, Bøgh KL, Dupont D, Egger L, Gadermaier G, Larré C, Mackie A, Menard O, Adel-Patient K, Picariello G, Portmann R, Smit J, Turner P, Untersmayr E, Epstein MM (2019) The relevance of a digestibility evaluation in the allergenicity risk assessment of novel proteins. Opinion of a joint initiative of COST action ImpARAS and COST action INFOGEST. Food Chem Toxicol 129:405-423. https://doi.org/10.1016/j.fct.2019.04.052

207. Di Stasio L, Picariello G, Mongiello M, Nocerino R, Berni Canani R, Bavaro S, Monaci L, Ferranti P, Mamone G (2017) Peanut digestome: Identification of digestion resistant IgE binding peptides. Food Chem Toxicol 107:88-98. https://doi.org/10.1016/j.fct.2017.06.029

208. Smith F, Pan X, Bellido V, Toole GA, Gates FK, Wickham MSJ, Shewry PR, Bakalis S, Padfield P, Mills ENC (2015) Digestibility of gluten proteins is reduced by baking and enhanced by starch digestion. Mol Nutr Food Res 59:2034-2043. https://doi.org/10.1002/mnfr.201500262

209. Pasini G, Simonato B, Giannattasio M, Peruffo ADB, Curioni A (2001) Modifications of wheat flour proteins during in vitro digestion of bread dough, crumb, and crust: An electrophoretic and immunological study. J Agric Food Chem 49:2254-2261. https://doi.org/10.1021/jf0014260

210. Ma Y, Zuidmeer L, Bohle B, Bolhaar STH, Gadermaier G, Gonzalez-Mancebo E, Fernandez-Rivas M, Knulst AC, Himly M,
Asero R, Ebner C, Van Ree R, Ferreira F, Breiteneder H, Hoffmann-Sommergruber K (2006) Characterization of recombinant Mal d 4 and its application for component-resolved diagnosis of apple allergy. Clin Exp Allergy 36:1087-1096. https://doi.org/10.1111/j.1365-2222.2006.02541.x

211. López-Torrejón G, Crespo JF, Sánchez-Monge R, SánchezJiménez M, Alvarez J, Rodriguez J, Salcedo G (2005) Allergenic reactivity of the melon profilin Cuc $\mathrm{m} 2$ and its identification as major allergen. Clin Exp Allergy 35:1065-1072. https://doi.org/10.1111/j.1365-2222.2005.02303.x

212. Rodriguez-Perez R, Crespo JF, Rodríguez J, Salcedo G (2003) Profilin is a relevant melon allergen susceptible to pepsin digestion in patients with oral allergy syndrome. J Allergy Clinl Immunol 111:634-639. https://doi.org/10.1067/mai.2003.74

213. Kopper RA, Odum NJ, Sen M, Helm RM, Steve Stanley J, Wesley Burks A (2004) Peanut protein allergens: Gastric digestion is carried out exclusively by pepsin. J Allergy Clin Immunol 114:614-618. https://doi.org/10.1016/j.jaci.2004.05.012

214. Schulten V, Lauer I, Scheurer S, Thalhammer T, Bohle B (2011) A food matrix reduces digestion and absorption of food allergens in vivo. Mol Nutr Food Res 55:1484-1491. https://doi.org/10.1002/mnfr.201100234

215. Harrer A, Egger M, Gadermaier G, Erler A, Hauser M, Ferreira F, Himly M (2010) Characterization of plant food allergens: An overview on physicochemical and immunological techniques. Mol

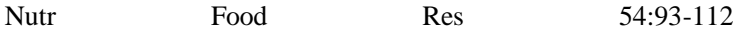
https://doi.org/10.1002/mnfr.200900096

216. Alcocer M, Rundqvist L, Larsson G (2012) Ber e 1 protein: the versatile major allergen from Brazil nut seeds. Biotechnol Lett 34:597-610. https://doi.org/10.1007/s10529-011-0831-1

217. Price DB, Ackland ML, Burks W, Knight MI, Suphioglu C (2014) Peanut allergens alter intestinal barrier permeability and tight junction localisation in Caco-2 cell cultures. Cell Physiol Biochem 33:1758-1777. https://doi.org/10.1159/000362956

218. Moreno FJ, Rubio LA, Olano A, Clemente A (2006) Uptake of $2 S$ albumin allergens, Ber e 1 and Ses i 1, across human intestinal epithelial Caco-2 cell monolayers. J Agric Food Chem 54:86318639. https://doi.org/10.1021/jf061760h

219. Teodorowicz M, Fiedorowicz E, Kostyra H, Wichers H, Kostyra E (2013) Effect of Maillard reaction on biochemical properties of peanut $7 \mathrm{~S}$ globulin (Ara h 1) and its interaction with a human colon cancer cell line (Caco-2). Eur J Nutr 52:1927-1938. https://doi.org/10.1007/s00394-013-0494-x

220. Mattison CP, Grimm CC, Wasserman RL (2014) In vitro digestion of soluble cashew proteins and characterization of surviving IgEreactive peptides. Mol Nutr Food Res 58:884-893. https://doi.org/10.1002/mnfr.201300299

221. Orruño E, Morgan MRA (2011) Resistance of purified seed storage proteins from sesame (Sesamum indicum L.) to proteolytic digestive enzymes. Food Chem 128:923-929. https://doi.org/10.1016/j.foodchem.2011.03.120

222. Sancho AI, Wangorsch A, Jensen BM, Watson A, Alexeev Y, Johnson PE, Mackie AR, Neubauer A, Reese G, Ballmer-Weber B, Hoffmann-Sommergruber K, Skov PS, Vieths S, Mills ENC (2011) Responsiveness of the major birch allergen Bet v 1 scaffold to the gastric environment: Impact on structure and allergenic activity. Mol Nutr Food Res 55:1690-1699. https://doi.org/10.1002/mnfr.201100025

223. Vickery BP, Chin S, Burks AW (2011) Pathophysiology of food allergy. Pediatr Clin N Am 58:363-376. https://doi.org/10.1016/j.pcl.2011.02.012

224. Sicherer SH (2011) Food Allergy. Mt Sinai J Med 78:683-696. https://doi.org/10.1002/msj.20292

225. Kleine-Tebbe J, Wangorsch A, Vogel L, Crowell DN, Haustein U-F, Vieths S (2002) Severe oral allergy syndrome and anaphylactic reactions caused by a Bet $\mathrm{v} 1-$ related PR-10 protein in soybean, SAM22. J Allergy Clin Immunol 110:797-804. https://doi.org/10.1067/mai.2002.128946

226. Klueber J, Costa J, Randow S, Codreanu-Morel F, Verhoeckx K, Bindslev-Jensen C, Ollert M, Hoffmann-Sommergruber K, Morisset M, Holzhauser T, Kuehn A (2020) Homologous tropomyosins from vertebrate and invertebrate: Recombinant calibrator proteins in functional biological assays for tropomyosin allergenicity assessment of novel animal foods. Clin Exp Allergy 50:105-116. https://doi.org/10.1111/cea.13503 
Table 1. Data on the composition and structure of proteins from the most important plant allergen families.

\begin{tabular}{|c|c|c|c|c|c|c|c|c|}
\hline & 2S Albumins & nsLTP & ATI & Cereal prolamins & Profilins & Legumins & Vicilins & PR-10 proteins \\
\hline Size (aa) & $130-160$ & $100-120$ & $120-160$ (subunit) & $\begin{array}{c}430-480 \text { (gliadin) } \\
\sim 380 \text { (LMW) } \\
\sim 850(\text { HMW) } \\
\end{array}$ & $\sim 130$ & $480-560$ & $500-600$ & $150-160$ \\
\hline MW (kDa) & $10-18$ & $9.5-10.5$ & 12-16 (subunit) & $\begin{array}{c}\text { 30-50 (gliadin) } \\
40 \text { (LMW) } \\
85-90 \text { (HMW) }\end{array}$ & $12-15$ & $\begin{array}{c}360 \\
\sim 60 \text { (subunit) }\end{array}$ & $\begin{array}{c}150-190 \\
40-80 \text { (subunit) }\end{array}$ & $15-17$ \\
\hline \begin{tabular}{|l|} 
Biological function \\
(Abundance)
\end{tabular} & \begin{tabular}{|c|} 
Seed storage proteins \\
(20-60\% depending on \\
species)
\end{tabular} & $\begin{array}{c}\text { Transport proteins. } \\
\text { (highly expressed in } \\
\text { pollens, leaves, fruit } \\
\text { peels) } \\
\text { (4\% of total proteins) }\end{array}$ & $\begin{array}{l}\text { Regulatory proteins. } \\
\text { (4\% of total proteins) }\end{array}$ & \begin{tabular}{|c|} 
Seed storage proteins. \\
(10-20\% glutenins, \\
$40-50 \%$ gliadins $)$
\end{tabular} & $\begin{array}{l}\text { Structural proteins. } \\
\text { (highly abundant in } \\
\text { all cells, especially in } \\
\text { pollen) }\end{array}$ & $\begin{array}{l}\text { Seed storage proteins. } \\
\text { (50-70\% depending on } \\
\text { species) }\end{array}$ & $\begin{array}{l}\text { Seed storage proteins. } \\
\text { ( 20\% depending on } \\
\text { species })\end{array}$ & $\begin{array}{l}\text { Regulatory proteins. } \\
\text { (highly expressed in } \\
\text { case of biotic stress) }\end{array}$ \\
\hline Protein structure & $\begin{array}{c}\text { Tertiary } \\
\text { Heterodimer }\end{array}$ & $\begin{array}{l}\text { Tertiary } \\
\text { Monomer }\end{array}$ & $\begin{array}{l}\text { Tertiary/quaternary } \\
\text { Homodimer }\end{array}$ & $\begin{array}{c}\text { Tertiary } \\
\text { Monomer (gliadin) } \\
\text { Polymer (glutenin) }\end{array}$ & $\begin{array}{l}\text { Tertiary } \\
\text { Monomer }\end{array}$ & $\begin{array}{l}\text { Quaternary } \\
\text { Hexamer }\end{array}$ & $\begin{array}{c}\text { Quaternary } \\
\text { Trimer or homotrimer }\end{array}$ & $\begin{array}{l}\text { Tertiary/quaternary } \\
\text { Monomer }\end{array}$ \\
\hline \begin{tabular}{|l|} 
Crystal structures \\
(Method: \\
X-ray diffraction)
\end{tabular} & & & & $\begin{array}{l}\text { No crystal structures } \\
\text { available for gliadins } \\
\text { or glutenins }\end{array}$ & & & & \\
\hline $\begin{array}{l}\text { Example of allergen } \\
\text { (source) }\end{array}$ & Peanut Ara h 6 & Peach Pru p 3 & Wheat Tri a 28 & Wheat & Birch pollen Bet v 2 & Soybean Gly m 6 & Peanut Ara h 1 & Celery Api g 1 \\
\hline $\begin{array}{l}\text { PDB accession } \\
\text { number }\end{array}$ & $1 \mathrm{~W} 2 \mathrm{Q}$ & 2B5S & $1 \mathrm{HSS}$ & $\mathrm{NR}$ & 1CQA & $2 \mathrm{D} 5 \mathrm{H}$ & $3 \mathrm{SMH}$ & $2 \mathrm{BK} 0$ \\
\hline
\end{tabular}

MW, molecular weight; aa, amino acid; NR, not reported; LMW, low molecular weight; HMW, high molecular weight; PDB, Protein Data Bank, https://www.rcsb.org/ . 
Table 2. Summary of the assays used to assess the effect of physicochemical parameters on the allergenicity of proteins from plant food families.

\begin{tabular}{|c|c|c|c|c|c|c|c|c|c|c|}
\hline \multirow[b]{2}{*}{ Families } & \multicolumn{3}{|c|}{ Specific serum screening } & \multicolumn{3}{|c|}{ Cellular in vitro or ex vivo assays } & \multicolumn{4}{|c|}{ In vivo assays } \\
\hline & $\begin{array}{c}\text { Immunoblot/ } \\
\text { dot blot }\end{array}$ & ELISA & $\begin{array}{l}\text { RAST/EAST/ } \\
\text { ImmunoCAP }\end{array}$ & $\begin{array}{c}\text { Basophil } \\
\text { activation test }\end{array}$ & $\begin{array}{l}\text { RBL mediator } \\
\text { release assay }\end{array}$ & $\begin{array}{c}\text { T-cell } \\
\text { proliferation }\end{array}$ & $\begin{array}{l}\text { Murine IgE } \\
\text { response }\end{array}$ & $\begin{array}{c}\text { Murine } \\
\text { anaphylaxis }\end{array}$ & $\begin{array}{c}\text { Human Skin } \\
\text { prick tests* }\end{array}$ & $\begin{array}{c}\text { Human Food } \\
\text { challenges* }\end{array}$ \\
\hline $2 \mathrm{~S}$ albumins & $\sqrt{ }$ & $\sqrt{ }$ & $\sqrt{ }$ & $\sqrt{ }$ & $\sqrt{ }$ & $\sqrt{ }$ & $\sqrt{ }$ & $\sqrt{ }$ & $\sqrt{ }$ & $\sqrt{ }$ \\
\hline nsLTP & $\sqrt{ }$ & $\sqrt{ }$ & $\sqrt{ }$ & $\sqrt{ }$ & $\sqrt{ }$ & NR & NR & NR & $\sqrt{ }$ & $\sqrt{ }$ \\
\hline ATI & $\sqrt{ }$ & $\sqrt{ }$ & NR & $\sqrt{ }$ & NR & $\sqrt{ }$ & $\sqrt{ }$ & NR & $\sqrt{ }$ & NR \\
\hline Cereal prolamins & $\sqrt{ }$ & $\sqrt{ }$ & $\sqrt{ }$ & $\sqrt{ }$ & $\sqrt{ }$ & $\sqrt{ }$ & $\sqrt{ }$ & $\sqrt{ }$ & $\sqrt{ }$ & $\sqrt{ }$ \\
\hline Profilins & $\sqrt{ }$ & $\sqrt{ }$ & $\sqrt{ }$ & NR & $\sqrt{ }$ & NR & NR & NR & $\sqrt{ }$ & $\sqrt{ }$ \\
\hline Legumins & $\sqrt{ }$ & $\sqrt{ }$ & NR & NR & $\sqrt{ }$ & $\sqrt{ }$ & NR & NR & $\sqrt{ }$ & NR \\
\hline Vicilins & $\sqrt{ }$ & $\sqrt{ }$ & $\sqrt{ }$ & $\sqrt{ }$ & $\sqrt{ }$ & $\sqrt{ }$ & NR & NR & $\sqrt{ }$ & $\sqrt{ }$ \\
\hline PR-10 & $\sqrt{ }$ & $\sqrt{ }$ & $\sqrt{ }$ & $\sqrt{ }$ & $\sqrt{ }$ & $\sqrt{ }$ & NR & NR & $\sqrt{ }$ & $\sqrt{ }$ \\
\hline
\end{tabular}

IL, interleukins; IFN, Interferons; RAST, radioallergosorbent test; EAST, enzyme allergosorbent test; RBL, rat basophilic leukaemia; ELISA, enzyme-linked immunosorbent assay; $\sqrt{ }$, confirmation of tests performed as reported on literature; NR, no evidence found in literature; * Human SPT and food challenges are normally performed using pure food extracts or entire food (either alone or hidden within a prepared matrix), respectively. 
Table 3. Summary of the physicochemical parameters and their effect on the allergenicity of different plant protein families

\begin{tabular}{|c|c|c|c|c|c|c|c|c|}
\hline $\begin{array}{l}\text { Physicochemical } \\
\text { Parameters }\end{array}$ & 2S Albumins & nsLTP & ATI & Cereal prolamins & Profilins & Legumins & Vicilins & PR-10 proteins \\
\hline PTM & $\begin{array}{l}\text { Glycosylation }(\uparrow \text { Pin } p 1) \\
\text { Hydroxylation }(\uparrow \text { Ara h } 2)\end{array}$ & NR & $\begin{array}{c}\text { Glycosylation }(\uparrow \text { Tri a } \\
40 \text { subunit } \mathrm{CM} 16)\end{array}$ & NR & NR & NR & $\uparrow$ (glycosylation) & NR \\
\hline Protein structure & $\begin{array}{l}\rightarrow \text { (Loss of 3D structure) } \\
\downarrow \text { (Reduction/alkylation) }\end{array}$ & $\rightarrow($ loss of 3D) & $\begin{array}{c}\downarrow \text { (Loss of 3D or 4D), } \\
\downarrow \text { (rupture of S-S) }\end{array}$ & $\begin{array}{c}\downarrow \text { (Loss of 2D), } \\
\downarrow \text { (rupture of S-S) }\end{array}$ & $\downarrow$ (Loss of 3D) & $\begin{array}{c}\downarrow \text { (Loss of 4D), } \\
\downarrow \text { (rupture of S-S) }\end{array}$ & $\rightarrow($ Loss of 4D) & $\downarrow$ (loss of 3D or 4D) \\
\hline \begin{tabular}{|l|} 
Glycation \\
\end{tabular} & $\uparrow \uparrow$ & $\rightarrow$ & NR & $\downarrow$ & NR & $\downarrow$ & $\rightarrow$ & $\downarrow, \rightarrow$ \\
\hline Aggregation & $\uparrow$ & No aggregation & NR & $\rightarrow$ & NR & $\downarrow$ & $\rightarrow$ & $\rightarrow($ for Ara h 8$)$ \\
\hline Heat stability & $\begin{array}{l}\text { Heat-stable: } \\
\uparrow \downarrow \text { (roasting), } \\
\downarrow \text { (boiling); } \\
\downarrow \text { (frying), } \\
\downarrow \text { (heat + pressure) }\end{array}$ & $\begin{array}{l}\text { Heat-stable: } \\
\rightarrow \text { (boiling); } \\
\rightarrow \text { (baking); } \\
\downarrow \text { (extreme heat) }\end{array}$ & $\begin{array}{c}\text { Heat-stable or heat- } \\
\text { labile? } \\
\downarrow \text { (boiling); } \\
\downarrow \text { (steaming); } \\
\downarrow \text { (extreme heat) }\end{array}$ & $\begin{array}{c}\text { Heat-stable: } \\
\downarrow \text { (heat treatments) }\end{array}$ & \begin{tabular}{|c|} 
Heat-labile: \\
$\downarrow$ (heat treatments)
\end{tabular} & $\begin{aligned} & \text { Heat-stable: } \\
& \rightarrow \text { (frying); } \\
\rightarrow \text { (dry roasting); } & \text { (blanching); } \\
& \downarrow \text { ( autoclaving); } \\
\downarrow & \text { (extreme heat) }\end{aligned}$ & $\begin{array}{c}\text { Heat-stable: } \\
\uparrow \text { (roasting), } \\
\downarrow \text { (boiling); } \\
\downarrow \text { (extreme heat) }\end{array}$ & $\begin{array}{l}\text { Heat-labile: } \\
\downarrow, \rightarrow \text { (roasting) }\end{array}$ \\
\hline Pressure stability & $\begin{array}{c}\text { Pressure-stable: } \\
\rightarrow \text { (HPP); } \\
\downarrow \text { (HP microfluidisation) }\end{array}$ & $\begin{array}{l}\text { Pressure-stable: } \\
\rightarrow \text { (HPP) } \\
\downarrow \text { (HPP + heat) }\end{array}$ & NR & NR & $\begin{array}{l}\text { Pressure-stable: } \\
\rightarrow(\mathrm{HPP})\end{array}$ & $\begin{array}{c}\text { Pressure-stable: } \\
\downarrow, \rightarrow \text { (HPP) } \\
\downarrow \text { (HPP + heat) }\end{array}$ & $\begin{array}{c}\text { Pressure-stable: } \\
\rightarrow \text { (HPP), } \\
\downarrow \text { (pressure + heat) }\end{array}$ & $\begin{array}{l}\text { Pressure stable: } \\
\quad \rightarrow \text { (HPP) }\end{array}$ \\
\hline $\begin{array}{l}\text { Light/radiation } \\
\text { stability }\end{array}$ & $\begin{array}{l}\text { Light-stable: } \\
\rightarrow \text { (microwave); } \\
\quad \downarrow \text { (PUV light) }\end{array}$ & $\begin{array}{l}\text { Light-stable: } \\
\rightarrow(\text { PEF }) ; \\
\rightarrow \text { (microwave }+ \\
\text { ultrasound })\end{array}$ & NR & $\begin{array}{l}\text { Light-stable: } \\
\uparrow \text { (microwave) }\end{array}$ & $\begin{aligned} & \text { Light-stable: } \\
\rightarrow & (\gamma \text {-radiation }) ; \\
\rightarrow \text { (high voltage } & \text { impulses }) ; \\
\downarrow & \text { (microwave })\end{aligned}$ & $\begin{array}{l}\text { Light-stable: } \\
\rightarrow(\gamma \text {-radiation }) ; \\
\rightarrow \text { (microwave); } \\
\downarrow \text { (PUV light })\end{array}$ & $\begin{array}{l}\text { Light-stable: } \\
\rightarrow(\gamma \text {-radiation }) ; \\
\rightarrow \text { (microwave); } \\
\downarrow \text { (PUV-light })\end{array}$ & $\begin{array}{l}\text { Light-stable: } \\
\downarrow \text { (microwave) }\end{array}$ \\
\hline $\begin{array}{l}\text { Mechanical/ } \\
\text { Chemical stability } \\
\text { (Protein integrity) }\end{array}$ & $\begin{array}{l}\downarrow \text { (alkylation/reduction), } \\
\rightarrow \text { (enzymatic hydrolysis) }\end{array}$ & $\rightarrow$ (ultrasound) & $\begin{array}{l}\downarrow \text { (enzymatic } \\
\text { hydrolysis) }\end{array}$ & $\begin{array}{c}\uparrow \downarrow \text { (enzymatic hydrolysis) } \\
\uparrow \downarrow \text { (deamidation of gliadins) }\end{array}$ & $\begin{array}{l}\rightarrow \text { (enzymatic } \\
\text { hydrolysis with } \\
\text { papain + heat })\end{array}$ & $\begin{array}{c}\downarrow \text { (fermentation; reducing } \\
\text { agents }+ \text { heat; or enzymatic } \\
\text { hydrolysis }+ \text { sonication }+ \\
\text { heat })\end{array}$ & $\downarrow$ (fermentation) & $\begin{array}{l}\downarrow \text { (enzymatic } \\
\text { hydrolysis) }\end{array}$ \\
\hline Digestibility & $\begin{aligned} \rightarrow & \text { (partial pepsin/trypsin); } \\
& \nearrow \text { (presence of lipids) }\end{aligned}$ & $\begin{array}{c}\rightarrow \text { (partial } \\
\text { degradation, most } \\
\text { peptides remain } \\
\text { reactive })\end{array}$ & $\begin{array}{c}\rightarrow \text { (resistant to } \\
\text { digestion) }\end{array}$ & $\begin{array}{c}\rightarrow \text { (partial degradation, most } \\
\text { peptides remain reactive })\end{array}$ & $\downarrow$ (after pepsin) & $\begin{array}{c}\downarrow \downarrow \text { (after pepsin); } \\
\rightarrow \text { (after trypsin); } \\
\downarrow \text { (after pepsin }+ \text { trypsin); } \\
\rightarrow, \nearrow \text { (presence of lipids) }\end{array}$ & $\begin{array}{c}\rightarrow \text { (after digestion), } \\
\rightarrow, \lambda \text { (presence of } \\
\text { lipids), } \\
\rightarrow, \lambda \text { (presence of } \\
\text { glycation } \\
\text { aggregates) }\end{array}$ & $\begin{array}{l}\downarrow \text { (after pepsin), } \\
\rightarrow, \nearrow \text { (presence of } \\
\quad \text { lipids) }\end{array}$ \\
\hline Epithelial transport & $\uparrow$ & $\uparrow$ & NR & $\uparrow$ & NR & NR & $\uparrow$ & NR \\
\hline $\begin{array}{l}\text { Lipid binding/ } \\
\text { lipid interaction }\end{array}$ & $\pi$ & $\uparrow$ & NR & NR & NR & $\rightarrow, \lambda$ & $\rightarrow, \nearrow$ & $\rightarrow$ \\
\hline
\end{tabular}

2D, secondary structure; 3D, tertiary structure; 4D, quaternary structure; HPP, high-pressure processing; S-S, disulphide bond; $\rightarrow$ maintain IgE-binding capacity; $\uparrow$ increase IgE-binding capacity; $\downarrow$ decrease IgE-binding capacity; $\uparrow \downarrow$ contradictory data about the effect on IgE-binding capacity; $\nearrow$ slightly increase IgE-binding capacity; NR, not reported; PEF, pulsed electric fields; PUV, pulsed ultraviolet. 
Table 4. Main conclusions about the adequacy of each physicochemical property as potentially shaping allergenicity.

\begin{tabular}{|c|c|c|}
\hline & $\begin{array}{l}\text { Impact on IgE-binding } \\
\text { capacity }\end{array}$ & Supporting evidence/Main concerns \\
\hline $\begin{array}{l}\text { ABUNDANCE } \\
\text { (allergen content in relation to total protein) }\end{array}$ & High & Potent allergens are often highly abundant. \\
\hline BIOLOGICAL FUNCTION & High & Potent allergens display biological functions as capacity, transport and defence. \\
\hline \multicolumn{3}{|l|}{ PTM } \\
\hline Glycosylation & Limited & Increases allergenicity, most likely IgE-binding regions containing N-glycans. Information mostly limited to vicilins \\
\hline Hydroxylation & Limited & Increase the allergenic potential of Ara $\mathrm{h} 2$ (limited to $2 \mathrm{~S}$ albumins) \\
\hline Phosphorylation & - & Not reported \\
\hline LIPID-BINDING & High & Lipid binding stabilises protein structure, increasing resistance to proteolysis and processing. \\
\hline \multicolumn{3}{|l|}{ PROTEIN STRUCTURE } \\
\hline Loss of 2D & High & Decreases allergenicity of most plant allergens. Loss of structural integrity. Valid for conformational epitopes \\
\hline Loss of S-S bonds & High & Decreases allergenicity of most plant allergens. Loss of structural integrity. Valid for conformational epitopes \\
\hline GLYCATION & Low or inconclusive & Depending on the protein family, glycation decreases, maintain or increase allergenicity \\
\hline AGGREGATION & Low or inconclusive & Depending on the protein family, aggregation decreases, maintain or increase allergenicity \\
\hline HEAT STABILITY & High & Potent allergens are heat stable. Fails to explain potent heat-labile allergens (e.g. profilins, PR-10 proteins) \\
\hline PRESSURE STABILITY & Limited & Potent allergens are pressure stable, but in vivo evidence has hardly been studied. Maintain protein integrity. \\
\hline LIGHT/RADIATION STABILITY & High & Potent allergens are light/radiation stable. Maintain protein integrity. \\
\hline MECHANICAL STABILITY & Low & Most allergens are stable to mechanical processing. Maintain protein integrity. \\
\hline \multicolumn{3}{|l|}{ CHEMICAL STABILITY } \\
\hline Changes in protein structure & High & Maintain or reduce the IgE-binding capacity. Limited information to nsLTP and legumins \\
\hline Changes in protein size (fragmentation) & High & $\begin{array}{l}\text { Maintain or reduce the IgE-binding capacity of } 2 \mathrm{~S} \text { albumins, ATI, legumins, vicilins, profilins and PR-10 families. } \\
\text { Fragmentation of protein into peptides. Loss of protein primary structure. }\end{array}$ \\
\hline Changes in protein size/structure & High & Enhance and maintain the IgE-binding capacity. Limited information to cereal prolamins and $2 \mathrm{~S}$ albumins \\
\hline \multicolumn{3}{|l|}{ DIGESTIBILITY } \\
\hline Pepsin resistance & Low or inconclusive & Fails to explain potent pepsin-labile allergens (e.g. Ara h 3, Gly m 6) \\
\hline Trypsin/chymotrypsin resistance & High & Most allergens are resistant to trypsin/chymotrypsin activities. \\
\hline Lipid interaction & High & Presence of lipids protects allergens from proteolysis. Maintain protein integrity. \\
\hline
\end{tabular}




\section{Figure Captions}

Figure 1 - Life cycle of food allergens: from intact source molecules to highly degraded peptides with immunological activity. 